\title{
A Better Approach for Balancing Authority and Accountability in Shareholder Derivative Litigation
}

\author{
Ann M. Scarlett ${ }^{*}$
}

\section{INTRODUCTION}

This decade has exposed numerous corporate scandals that have shaken shareholders, directors, and the markets. The wave of scandals that began in 2001 at corporations such as Enron and WorldCom revealed directors and officers out of control. ${ }^{1}$ Thereafter, a more insidious scandal struck, involving directors and officers backdating their stock options in their own self-interest at corporations such as Apple, McAfee, Monster, and Bed Bath \& Beyond. ${ }^{2}$ Congress, the SEC, and the listing companies responded to these scandals by imposing new, more restrictive requirements on corporations and their directors and officers. ${ }^{3}$ Shareholders also responded with attempts to take more control of the corporations in which they hold stock on issues such as environmental

Assistant Professor of Law, Saint Louis University. This Article has benefited from comments by participants at Washington University's Regional Junior Faculty Works-in-Progress workshop, by participants at a faculty colloquium of the University of Oklahoma College of Law, and by my colleagues in a summer workshop at Saint Louis University. I thank Patrick Pedano and Stephanie Gwillim for their excellent research assistance.

1. See, e.g., E. Norman Veasey, State-Federal Tension in Corporate Governance and the Professional Responsibilities of Advisors, 28 J. CORP. L. 441, 441-42 (2003) (noting the Enron and WorldCom scandals revealed that "(1) officers ran amok, wallowing in greed-driven schemes and other abuses; and (2) directors allowed it to happen, tolerating officers who were managing to the market while they contented the directors with ever-rising stock prices").

2. Charles Forelle \& James Bandler, As Companies Probe Backdating, More Top Officials Take a Fall, WALL ST. J., Oct. 12, 2006, at A1 (discussing the backdating scandals occurring at, among others, Apple Computer Inc., McAfee Inc., Monster Worldwide Inc., and Bed Bath \& Beyond Inc.).

3. See, e.g., Sarbanes-Oxley Act of $2002 \S 302,15$ U.S.C. § 7241 (Supp. IV 2004); id. § 301, 15 U.S.C. $\S 78 \mathrm{j}-1(\mathrm{~m})$ (forcing listing companies to impose more restrictive requirements on public companies); NYSE, Inc., Listed Company Manual § 303A.02 (2004) (stating new, more restrictive definition of director independence); NASDAQ, Inc., Marketplace Rules, R. 4200(a)(15) (2004) (similar). As argued elsewhere, the Delaware courts also responded to the recent scandals by allowing more cases to survive pretrial motions asserting the business judgment defense, but they have not altered the current formulation of the business judgment rule. Ann M. Scarlett, Confusion and Unpredictability in Shareholder Derivative Litigation: The Delaware Courts' Response to Recent Corporate Scandals, 60 FLA. L. REV. 589, 603-04 (2008). 
standards and labor rights, as well as on matters that may entrench directors in their positions or lead directors to promote their own interests at the expense of shareholders. ${ }^{4}$ Yet, litigation remains a device commonly employed by shareholders when boards of directors abuse their power. Recent shareholder derivative actions against Apple, Citigroup, Tyson Foods, Walt Disney, and Enron, among others, demonstrate that judicial recourse remains a powerful tool used by shareholders. ${ }^{5}$

Shareholder derivative litigation, however, rarely succeeds in holding directors liable for their decisions. One reason is the business judgment rule defense, which protects boards of directors from legal liability in most such cases. ${ }^{6}$ Under courts' current formulation, the business judgment rule operates as a presumption that the defendantdirectors have acted consistent with their fiduciary duties. ${ }^{7}$ If the plaintiff-shareholders cannot rebut this presumption, then the defendantdirectors cannot be held liable. ${ }^{8}$ In the unlikely event that the plaintiffshareholders rebut the presumption, then the defendant-directors must prove that the challenged transaction was fair to the corporation. ${ }^{9}$

Yet, despite evidence that shareholders rarely rebut the business judgment rule presumption and even in the aftermath of the recent scandals, some corporate scholars assert that courts are not providing sufficient protection to directors' decisions under current law. ${ }^{10}$ Other scholars, however, claim that courts should exercise broader review of directors' decisions. ${ }^{11}$ The true debate concerns the proper balancing point between directors' authority to make decisions for the corporation and shareholders' right to hold directors accountable for their decisions. ${ }^{12}$

4. See infra Part III.C.2.

5. Disputes between shareholders and directors and officers may be resolved through quasijudicial means such as arbitration, but judicial recourse remains the norm today.

6. See Omnicare, Inc. v. NCS Healthcare, Inc., 818 A.2d 914, 927 (Del. 2003) (“The business judgment rule, as a standard of judicial review, is a common-law recognition of the statutory authority to manage a corporation that is vested in the board of directors." (quoting MM Cos. v. Liquid Audio, Inc., 813 A.2d 1118, 1127 (Del. 2003))); Smith v. Van Gorkom, 488 A.2d 858, 872 (Del. 1985) (stating the business judgment rule "protect[s] and promote[s] the full and free exercise of the managerial power granted to Delaware directors"), superseded by statute, DEL. CODE ANN. Tit. 8, § 102(b)(7) (1986), as recognized in Emerald Partners v. Berlin, 787 A.2d 85 (Del. 2001).

7. See In re The Walt Disney Co. Derivative Litig., 906 A.2d 27, 52 (Del. 2006); see also infra Part III.A.

8. See Citron v. Fairchild Camera \& Instrument Corp., 569 A.2d 53, 64 (Del. 1989).

9. See In re Walt Disney, 906 A.2d at 52.

10. See infra Part III.C.

11. See infra Part III.B.

12. Cf. Stephen M. Bainbridge, The Business Judgment Rule as Abstention Doctrine, 57 VAND. L. REV. 83, 109 (2004) ("Establishing the proper mix of deference and accountability thus emerges 
A balancing point that prohibits director liability in all but the most egregious cases would fulfill the purposes that originally led to the creation of the business judgment rule, such as protecting directors from Monday morning quarterbacking by shareholders, from honest mistakes of judgment, and from unpopular decisions. ${ }^{13}$ But finding a balancing point that respects directors' authority, without completely eliminating the possibility of holding directors accountable for decisions not made in the best interests of the corporation, proves difficult in theory and in application.

Even if corporate scholars could agree on the proper balancing point between authority and accountability, a complex problem of procedure needs to be resolved. In a shareholder derivative action, the plaintiffshareholders seek to hold the defendant-directors accountable for their decisions and the defendant-directors inevitably assert that their decisions are protected by the business judgment rule. Thus, the business judgment rule operates as the mechanism that balances the directors' legal authority to manage the corporation against the shareholders' right to hold those directors accountable for the decisions they make on behalf of the corporation. ${ }^{14}$ Because the business judgment rule is the mechanism by which courts balance authority and accountability, courts need a framework for applying the business judgment rule that achieves the desired balancing point.

The authority versus accountability dilemma is not unique to corporations; it is prevalent throughout the law. For instance, much scholarship has been devoted to that dilemma in the areas of international law and administrative law. ${ }^{15}$ However, corporate scholars have not explored the insights this scholarship may offer for corporate law. This Article will do so. Part II discusses the authority versus accountability dilemma by drawing upon the literature discussing that dilemma in other areas of law. Section A examines the informal methods of accountability that have been identified through this literature, and analyzes how these methods may apply in the corporate context. Section B then examines the formal methods of accountability and explores specific examples for the insights they may offer for corporate law.

as the central problem in applying the business judgment rule to particular situations.”).

13. See infra Part III.A.

14. See Bainbridge, supra note 12 , at 87 (arguing "that the business judgment rule is the principal mechanism by which corporate law resolves that tension"); id. at 84 (describing the business judgment rule as being "designed to effect a compromise - on a case-by-case basisbetween two competing values: authority and accountability").

15. See infra Part II. 
Part III analyzes the authority versus accountability dilemma presented in the corporate context. In Section A, the Article focuses on legal accountability and describes the balancing of authority and accountability that occurs in shareholder derivative litigation through the current formulation of the business judgment rule. Section B then examines and rejects corporate scholars' proposals seeking to shift the balance more toward accountability in shareholder derivative litigation, including a proposal to abolish the business judgment rule and proposals to permit broader judicial review of directors' decisions. Section $C$ then analyzes a recent proposal seeking to shift the balance more toward authority, by having courts adopt an abstention doctrine approach to the business judgment rule. It demonstrates that the proposed abstention approach does not offer an effective replacement for the current formulation of the business judgment rule and that courts are unlikely to adopt it.

Having rejected corporate scholars' proposals for shifting the balance between authority and accountability in Part III, Part IV advocates for a new approach to the business judgment rule that offers a more effective framework for courts performing such balancing in shareholder derivative litigation. Section A examines the benefits of a procedural mechanism versus a substantive mechanism for balancing authority and accountability in shareholder derivative litigation. After recognizing the advantages of a procedural mechanism, Section B explains the benefits of applying the procedures surrounding the qualified immunity doctrine to the business judgment rule defense.

\section{THE Authority Versus ACCOUNTABILITY DiLEMMA}

The authority versus accountability dilemma can be seen in all facets of life as well as in the law. Parents may give their teenager the authority to use one of the family's cell phones, but will hold the teenager accountable if he exceeds the phone's pre-paid minutes. A law firm may give their associates the authority to use the internet in performing their job functions, but will hold them accountable if they visit websites unrelated to their work such as pornography websites or their MySpace pages. ${ }^{16}$ A presidential election offers a more complex example of the authority versus accountability debate. When voters elect an individual

16. Perhaps to some degree these examples reflect a sentiment to "trust but verify." See generally Ronald Reagan, U.S. President, Farewell Address to the Nation (Jan. 11, 1989), available at http://www.reaganfoundation.org/reagan/speeches/farewell.asp (describing how the United States should act toward the former Soviet Union). 
to the Presidency (albeit indirectly through the Electoral College), they are concerned whether that President will act in their best interests: the President possesses substantial authority, but cannot effectively be held accountable for specific actions ${ }^{17}$ except through voters' power not to reelect that President to a second term or perhaps through impeachment. ${ }^{18}$

Whenever one person (the principal) entrusts another (the agent) with authority to act, a classic agency problem is presented. ${ }^{19}$ The principal delegates certain authority to the agent to act on the principal's behalf. The principal, however, also wants the ability to hold the agent accountable if the agent fails to complete the assigned tasks or exceeds the authority given by the principal. For a principal to hold an agent accountable, the principal first must know what the agent has done and also must have the ability to impose adverse consequences on the agent. Thus, "measures to assure accountability require mechanisms for transmission of information as well as enforcement." ${ }^{20}$ The classic

17. In some respects, the Framers of the Constitution perhaps did not intend for the President to be subject to any accountability. For instance, the Framers allocated to the President the sole power to wage war and the sole authority to grant pardons.

Of all the cares or concerns of government, the direction of war most peculiarly demands those qualities which distinguish the exercise of power by a single hand. The direction of war implies the direction of the common strength; and the power of directing and employing the common strength, forms a usual and essential part in the definition of the executive authority.... He is also to be authorized to grant "reprieves and pardons for offenses against the United States, EXCEPT IN CASES OF IMPEACHMENT.”. . . As the sense of responsibility is always strongest, in proportion as it is undivided, it may be inferred that a single man would be most ready to attend to the force of those motives which might plead for a mitigation of the rigor of the law, and least apt to yield to considerations which were calculated to shelter a fit object of its vengeance. The reflection that the fate of a fellow-creature depended on his sole fiat, would naturally inspire scrupulousness and caution; the dread of being accused of weakness or connivance, would beget equal circumspection, though of a different kind. On the other hand, as men generally derive confidence from their numbers, they might often encourage each other in an act of obduracy, and might be less sensible to the apprehension of suspicion or censure for an injudicious or affected clemency. On these accounts, one man appears to be a more eligible dispenser of the mercy of government, than a body of men.

THE FEDERALIST No. 74 (Alexander Hamilton).

18. The President has presidential immunity for his or her official acts. See Clinton v. Jones, 520 U.S. 681, 696 (1997) ("With respect to acts taken in his 'public character' - that is, official acts - the President may be disciplined principally by impeachment, not by private lawsuits for damages.").

19. See generally William A. Gregory, The LaW of AgENCY AND PARTNERShiP, $\S 1$, at $2-4$ (3d ed. 2001).

20. Robert O. Keohane \& Joseph S. Nye, Jr., Democracy, Accountability and Global Governance 3-4 (Harv. Univ. John F. Kennedy Sch. of Gov't, Politics Research Group, Working Paper No. 01-4, 2001) ("Accountable actions are explainable and sanctionable. Principals can require agents to give reasons so that they can make judgments about their actions. Thus some degree of transparency is essential for accountability. Principals can also directly or indirectly sanction their agents if displeased with their actions."). 
agency problem becomes more complex in the corporate context, but the tension between authority and accountability remains. ${ }^{21}$

\section{A. Accountability Through Informal, Non-Legal Methods}

Shareholder derivative litigation is not the only possible check on directors' actions, as informal accountability mechanisms do exist. A broad and diverse literature has developed on the topic of accountability, which identifies at least four informal processes through which accountability can occur: (1) electoral accountability, (2) hierarchical accountability, (3) reputational accountability, and (4) market accountability. $^{22}$ Many of these informal accountability mechanisms apply in the corporate context and may act as restraints on directors' authority at least to some degree.

Perhaps the most common example of an informal accountability mechanism is electoral accountability, which can be seen in the democratic elections that occur every year in the United States. ${ }^{23}$ Electoral accountability is also exercised at corporations' annual meetings of shareholders, when shareholders vote in person or by proxy for the next year's board of directors. ${ }^{24}$ Shareholders elect the directors of the corporation ${ }^{25}$ and the law vests those directors with almost unlimited authority to manage the corporation. ${ }^{26}$ Because shareholders

21. Some corporate scholars disagree that an agency relationship exists between directors and shareholders, but even under the director primacy theory directors are supposed to act in the best interests of shareholders and thus the authority versus accountability dilemma still exists. See, e.g., Stephen M. Bainbridge, Director Primacy: The Means and Ends of Corporate Governance, 97 Nw. U. L. REV. 547 (2003) [hereinafter Bainbridge, Director Primacy].

22. Keohane \& Nye, supra note 20, at 4-5; see also Global Governance AND PUBLIC ACCOUnTABILITY 74-76 (David Held \& Mathias Koenig-Archibugi eds., 2004) (explaining the various accountability mechanisms such as peer accountability, public reputational accountability, market accountability, financial accountability, and legal accountability that are important within networks while noting that electoral accountability and hierarchical accountability are not applicable in networks); Erik B. Bluemel, Overcoming NGO Accountability Concerns in International Governance, 31 BROOK. J. INT'L L. 139, 149-54 (2005) (describing accountability mechanisms as including fiscal, market, supervisory, legal, peer, market, reputational, and hierarchical); Orna Rabinovich-Einy, Technology's Impact: The Quest for a New Paradigm for Accountability in Mediation, 11 HARV. NEGOT. L. REV. 253, 261 (2006) (stating that accountability can be created through informal mechanisms such as "by relying on professionalism or market forces to curb decision-maker discretion and encourage voluntary information disclosure on actions and related outcomes").

23. Keohane \& Nye, supra note 20 , at 4-5.

24. Del. Code ANN. tit. 8, § 211(b) (2008); MOdEL Bus. CORP. ACT § 8.03(c) (2007).

25. See, e.g., DEL. CodE ANN. tit. 8, §§ 211(b)-212(b) (2008); ModEL Bus. Corp. ACT $\S \S$ $7.28,8.03(\mathrm{c})(2007)$.

26. See, e.g., DEL. CODE ANN. tit. 8, § 141(a) (2008) (stating "[t]he business and affairs of every corporation ... shall be managed by or under the direction of a board of directors"); MODEL 
elect the directors, an observer might think that shareholders possess the ability to hold directors accountable for the decisions they make on behalf of the corporation. In theory, if a corporation's shareholders believe that the current directors are not acting in the best interests of the corporation, they may hold those directors accountable for their decisions by voting them out of office through the election of new directors to the board. ${ }^{27}$ In reality, shareholders have limited ability to hold directors accountable for their decisions. Shareholders possess "no power to initiate corporate action" 28 and possess the right to vote on only a few matters such as election of directors, mergers, sales, dissolution, and amendments to the corporate charter and bylaws. ${ }^{29}$ Even director elections are essentially determined by the existing board, because the existing board typically nominates the slate of directors on which shareholders then vote. ${ }^{30}$ When a group of shareholders wants to nominate their own slate of directors, they typically must mount a costly and difficult proxy contest. ${ }^{31}$ Thus, shareholders often resort to filing a lawsuit on behalf of the corporation, which is called a shareholder derivative lawsuit, when they believe that the directors have not acted in the best interests of the corporation or that the directors have abused their power. $^{32}$

Any classic agency relationship, such as the employer-employee relationship, represents hierarchical accountability. ${ }^{33}$ For instance, when the board of directors hires a CEO to run the daily affairs of the

BUS. CORP. ACT $\S 8.01$ (b) (2007) (“All corporate powers shall be exercised by or under the authority of ... and the business and affairs of the corporation ... managed by or under the direction [of] ... its board of directors ....").

27. Cf. Keohane \& Nye, supra note 20, at 3 ("Accountability can be created through actions 'in the shadow of elections."').

28. Bainbridge, supra note 12, at 105.

29. Id. at $105 \mathrm{n} .133$ (listing shareholder rights as "election of directors and approval of charter or by-law amendments, mergers, sales of substantially all of the corporation's assets, and voluntary dissolution"). Bainbridge also notes that "only electing directors and amending the by-laws do not require board approval before shareholder action is possible." Id. at 105-06 n.133 (citing DEL. CODE ANN. tit. 8, §§ 109, 211); see also Bainbridge, Director Primacy, supra note 21, at 569-72 (discussing the weak control rights of shareholders).

30. Bainbridge, supra note 12, at $105-06 \mathrm{n} .133$.

31. Robert Charles Clark, Corporate LAW, § 9.5.4, 394-96 (1986). However, the advent of electronic proxy voting may make such proxy contexts cheaper and easier. Lynn A. Stout, The Mythical Benefits of Shareholder Control, 93 VA. L. REV. 789, 807 n.47 (2007) (stating that electronic proxy voting may "make it much cheaper and easier for dissenting shareholders to mount a proxy battle").

32. See ClARK, supra note 31, at 396 ("The derivative suit, or action brought on behalf of the corporation by a shareholder, solves collective action problems in an ingenious way.").

33. Cf. Keohane \& Nye, supra note 20, at 12 ("In the international organizational model, the principal form of accountability is hierarchical: of agents to principals."). 
corporation, the CEO is accountable to the board of directors. ${ }^{34}$ Thus, the board can fire the CEO at any time if the CEO does not act consistent with the board's instructions or, more generally, does not act in the best interests of the corporation. ${ }^{35}$ This hierarchical relationship is duplicated through every employee hired within the corporation. ${ }^{36}$ The shareholders and the directors, however, do not have a typical hierarchical relationship. In theory, shareholders can remove directors from office at any time with or without cause, but such power often is restricted and shareholders can rarely coordinate such action. ${ }^{37}$

Reputational accountability refers to the embarrassment and damage that people may suffer if their poor choices or bad acts become known. ${ }^{38}$ Thus, as applied to corporations, directors will theoretically act in the best interests of the corporation for fear of damaging their professional and personal reputations. ${ }^{39}$ Obviously, a key to such accountability is awareness of the directors' actions by the people to whom the directors feel connected either professionally or personally. If directors' actions are not transparent and are not publicly known, they need not fear reputational accountability. Thus, publicity and transparency are vital to proper functioning of reputational accountability. ${ }^{40}$

A similar restraint on directors may occur through market accountability, such as when corporations are held responsible by consumers. ${ }^{41}$ In other words, "market forces [may] curb decision-maker discretion and encourage voluntary information disclosure on actions and related outcomes." ${ }^{22}$ This form of accountability can be seen in corporations' voluntary disclosures of adverse information in advance of

34. See Stephen M. BainBridge, Corporation LaW And Economics, § 5.8, 231-40 (2002); CLARK, supra note $31, \S 3.3 .1$, at 114 .

35. See BAINBRIDGE, supra note 34, at 231 (stating "all corporate powers are exercised by or under the board's authority - which includes the power to hire and fire").

36. Cf. id. ("In turn, corporate officers may delegate some of their responsibilities to less senior employees, and so forth down the organizational chart.").

37. See, e.g., Del. CodE ANN. tit. 8, § 141(k) (2008); Model Bus. CorP. ACt § 8.08 (2007).

38. See Keohane \& Nye, supra note 20, at 5 ("Reputational accountability occurs through publicity."); Rabinovich-Einy, supra note 22, at 261 (stating that accountability can be created through informal mechanisms such as "by relying on professionalism or market forces to curb decision-maker discretion and encourage voluntary information disclosure on actions and related outcomes").

39. See Keohane \& Nye, supra note 20, at 17 ("Reputational accountability is crucial: without credibility, organizations and groups cannot become accepted as participants in the ongoing bargaining processes that produce outcomes.").

40. Id. at 5 .

41. Id.

42. Rabinovich-Einy, supra note 22 , at 261 ; see also Keohane \& Nye, supra note 20 , at 3 ("Accountability can also be accomplished through markets, and as [a] result of publicity."). 
such information being made public through other means, as well as corporations' general concern about stock price. Directors, both individually and as a board, can also exercise internal accountability through self-evaluation and internal review. ${ }^{43}$

These informal methods of accountability can be seen in other areas of law that also face the authority versus accountability dilemma. The following sections briefly describe the authority versus accountability dilemmas presented in international law and administrative law, and demonstrate the functioning of the informal methods of accountability within these contexts. Although the authority versus accountability dilemmas in international law and administrative law may be more complicated than the modern corporation, they reveal the limitations and ineffectiveness of informal methods of accountability.

\section{International Law}

In modern times, nations have consented to the formation of international organizations to facilitate nations' relationships on such matters as international trade, international environmental standards, and international crimes. The nature and extent of these international organizations' authority varies as does the accountability of such organizations, but these various international organizations typically possess the authority to promulgate substantive rules that will affect private transactions and that often will supplant national law with international rules and standards. ${ }^{44}$ Their authority arises from the treaty commitments of their member nations. ${ }^{45}$ However, these international organizations' authority to act is not absolute, as the international rules and standards they promulgate often require enforcement as well as implementation by member nations' courts, administrative agencies, and legislative bodies. ${ }^{46}$

43. Rabinovich-Einy, supra note 22, at 261.

44. Paul B. Stephan, The New International Law-Legitimacy, Accountability, Authority, and Freedom in the New Global Order, 70 U. ColO. L. REV. 1555, 1556-57 (1999); Sidney A. Shapiro, International Trade Agreements, Regulatory Protection, and Public Accountability, 54 ADMIN. L. REV. 435, 436 (2002) ("The public has an important stake in the adoption of international standards.").

45. Stephan, supra note 44, at 1556-57.

46. See, e.g., Shapiro, supra note 44, at 436 (stating "the government can make important decisions concerning the enforcement of international standards in the United States without effective public participation"); Stephan, supra note 44, at 1557 (citing NAFTA as one such example); Paul B. Stephan, Accountability and International Lawmaking: Rules, Rents and Legitimacy, 17 Nw. J. INT'L L. \& BuS. 681, 688 (1996) [hereinafter Stephan, Accountability] (“Aside from the indirect discipline that voters impose on legislators and executives who participate in 
Despite the somewhat limited authority possessed by some international organizations, many scholars argue that international lawmaking "suffers from an accountability deficit." "Rules that may have a real impact on the affairs of workers, consumers, entrepreneurs, and other people can come into force without those persons having either an adequate opportunity to influence their content ... or to elect out of their application . ..."48 In other words, these international organizations may grant rights to and impose obligations on private individuals but give those individuals "a diminished role in the development and implementation of these rights and duties." 49

Accountability does exist in international law, but to a limited degree. $^{50}$ For instance, international lawmakers face even weaker electoral accountability than domestic lawmakers. ${ }^{51}$ Although the member nations generally appoint their own bureaucratic representatives to serve on these international lawmaking bodies, these individuals are accountable only indirectly to the voters of their member nations. ${ }^{52}$ However, some executives of international organizations stand for direct elections by member nations. ${ }^{53}$ Hierarchical accountability also is minimal in this context. Although member nations typically must "agree in advance to the international commitments that [in turn] bind private actors,"

international lawmaking, the principal mechanism for limiting the effect of international public legislation is the opportunity member states have to choose how to implement what the international body enacted.").

47. Stephan, supra note 44, at 1562; Stephan, Accountability, supra note 46, at 735 .

48. Stephan, supra note 44, at 1562; see also Shapiro, supra note 44, at 449-50 (explaining that the public has limited ability to participate in the creation of international standards).

49. Stephan, supra note 44, at 1563; see also ReSTATEMENT (THIRD) FOREIGN RELATIONS LAW OF THE UNITED STATES $§ 101$ (1986) (declaring that international law includes rules governing nations' "relations with persons, whether natural or juridical").

50. See Keohane \& Nye, supra note 20, at 4 (describing international law as hierarchical accountability, which can be seen in member nations' power to remove the head of an international organization, rules restricting the discretion of such organizations, and member nations withholding their budgetary contributions).

51. Stephan, Accountability, supra note 46, at 682; see also Keohane \& Nye, supra note 20, at 12 ("[I]n contrast to the realist world of untrammeled state power, the international organizational model builds-in a set of restraints - however weak they may be - on the exercise of power."); Stephan, supra note 44, at 1578 ("The processes that generate the new international law are several steps removed from the usual mechanisms that hold lawmakers accountable for their decisions.").

52. Keohane \& Nye, supra note 20, at 2-3; Michael A. Livermore, Note, Authority and Legitimacy in Global Governance: Deliberation, Institutional Differentiation, and the Codex Alimentarius, 81 N.Y.U. L. REV. 766, 778 (2006).

53. Keohane \& Nye, supra note 20, at 12; Stephan, Accountability, supra note 46, at 682; see also Stephan, supra note 44, at 1578 ("The processes that generate the new international law are several steps removed from the usual mechanisms that hold lawmakers accountable for their decisions.").

54. Stephan, supra note 44, at 1579; see also Stephan, Accountability, supra note 46, at 687 
promulgated by these international organizations. The exercise of the authority delegated to international lawmakers is not always subject to subsequent legislative ratification by member nations. " $[\mathrm{M}]$ ost national legislatures have only two means of disciplining international lawmakers, because substituting a different rule is not an option. They can reject the rule generated through the international process, or they can withhold funds from the lawmaking body." ${ }^{, 56}$ Much scholarship has argued that the absence of direct accountability threatens the legitimacy of the rules promulgated by these international organizations. ${ }^{57}$

Although international organizations may not be effectively held accountable through electoral accountability or hierarchical accountability, ${ }^{58}$ they can potentially be held accountable through the informal accountability methods of market accountability and reputational accountability. ${ }^{59}$ They also can be held accountable through rules governing how the organizations can operate, which may be monitored by independent organizations and courts. ${ }^{60}$ Similarly, monitoring activities by nations and their representatives potentially provide accountability of the international organizations to the member nations. ${ }^{61}$ Indeed, one of the common suggestions for improving the accountability of international organizations is to reform the process to achieve greater transparency and thus greater public participation. ${ }^{62}$

("More often, legislatures rely on the terms by which they initially accede to an international organization to limit what their executives, acting through those organizations, can accomplish. And when international organizations later supersede such restrictions, the legislature may be left with a take-it-or-leave-it proposition. At a minimum, it will not be able to modify what the organization produces without forcing an additional round of negotiations. And if it refuses to accept the internationally agreed product and cannot force other countries to make changes, the legislature either will have to accede to an action that disregards its previous instructions or force the executive to resign from the organization.").

55. Stephan, Accountability, supra note 46, at 682; Keohane \& Nye, supra note 20, at 12; see also Stephan, supra note 44, at 1578 ("The processes that generate the new international law are several steps removed from the usual mechanisms that hold lawmakers accountable for their decisions.").

56. Stephan, Accountability, supra note 46, at 682-83.

57. Livermore, supra note 52, at 778-79; Keohane \& Nye, supra note 20, at 2-3; see also Simon Burall \& Caroline Neligan, The Accountability of International Organizations, GLOBAL Public Policy Institute Research PAPer Series No. 2, at 9 (2005) (noting that "the accountability mechanisms in place to ensure formal accountability do not work" in the context of IGOs and that increasing the accountability of IGOs will "require more robust internal accountability processes and a greater openness to external stakeholders"); Ngaire Woods, Good Governance in International Organizations, 5 GloBAL GOVERNANCE 39, 44 (1999) (noting that accountability is lacking in many international organizations).

58. Keohane \& Nye, supra note 20, at $1-2$.

59. Id. at 3,17 .

60. Id. at 3 .

61. Id.

62. See Shapiro, supra note 44 , at $457-58$ (stating that "recommendation[s] focus[] on 
However, without enforcement mechanisms, transparency alone does not solve the accountability equation.

Admittedly, the authority possessed by these international organizations varies greatly, as do the mechanisms by which they may potentially be held accountable by member nations, but informal methods of accountability reign in this context. And despite the extensive scholarship devoted to the authority versus accountability debate in the context of international law, international law does not seem to have achieved a satisfactory balancing of authority and accountability across these international organizations. Indeed, the balance in international law appears strongly tilted toward authority as shown by the voluminous scholarship calling for more accountability over international organizations.

\section{Administrative Law}

The United States has numerous administrative agencies that impact the public as well as private individuals in areas such as health, education, and housing. Congress gives these agencies the power to exercise authority by statute, without any specific constraints on their administrative discretion. ${ }^{63}$ Thus, these agencies' power to affect regulation in their given area is largely unchecked. ${ }^{64}$

Hierarchical accountability is weak in the context of administrative law. Although the President possesses the power to appoint and remove the heads of the various agencies, such power only permits the President to indirectly affect the actions of such agencies. ${ }^{65}$ Because the executive branch possesses such power, the public arguably holds some degree of electoral accountability, but this is an even weaker means of indirect

transparency as a key procedural instrument to invoke more effective public participation"); Stephan, supra note 44 , at 1580 .

63. Lisa Schultz Bressman, Beyond Accountability: Arbitrariness and Legitimacy in the Administrative State, 78 N.Y.U. L. REV. 461, 496 (2003).

64. Jeffrey Rudd, Restructuring America's Government to Create Sustainable Development, 30 WM. \& MARY ENVTL. L. \& POL'y ReV. 371, 386 (2006). Rudd proposes fixing this nonaccountability by having Congress limit administrative agency discretion and enact specific legislation providing penalties when agency heads fail to properly use their discretion, and also by reinstating judicial review of agency actions. Id. at 464-69.

65. Bressman, supra note 63, at 466, 486-91; Cynthia R. Farina, Statutory Interpretation and the Balance of Power in the Administrative State, 89 COLUM. L. REv. 452, 504 (1989) ("Control over the power to appoint key government officials was an issue of intense concern for the Framers. Article II, section 2 of the Constitution, providing for presidential appointment of major officers with Senate consent, represented a deeply considered and much debated attempt to balance executive and legislative involvement in the selection process.”). 
accountability. ${ }^{66}$ Similarly, such power arguably provides some degree of transparency, which may deter improper motives and may indirectly allow the public to assign blame for any improper exercise of agency power. ${ }^{67}$ Yet, many commentators opine that the public lacks sufficient means to hold an agency accountable when that agency abuses its authority. Typically, in the context of governments, "[w]hen the state makes demands of its subjects, accountability means that the subjects have some means of affecting those demands, either by choosing in some fashion who may exercise the power to make those demands (voice) or by taking steps to place themselves outside their scope (exit)." ${ }^{" 68}$ Neither option exists in the public's relationship with administrative agencies. Just as with international law, the balance appears weighted strongly toward authority.

Arguably these administrative agencies present a close analogy to corporations. Voters elect the President (albeit indirectly through the Electoral College), and the President then appoints agency heads to act consistent with the President's view of wise policy choices as explained to voters during the campaign. The President's power to hold a particular agency accountable for its actions is limited to removing the politically-appointed agency head. The public, however, has virtually no means to hold the agency accountable, although the public is the primary recipient of the agency's actions whether favorable or unfavorable. Similarly, shareholders elect directors to make business decisions for the corporation, and those directors in turn appoint officers to run the daily business of the corporation. The directors have the ability to remove these officers from their positions as well as the legal authority to approve certain actions. The shareholders, however, cannot hold these officers accountable, although the shareholders indirectly can do so by not re-electing the directors at the next annual meeting.

\section{B. Accountability Through Formal, Legal Methods}

As demonstrated in the prior section, informal methods produce weak accountability. Accountability, however, can also be created through formal mechanisms - "those that are derived from a legal source (superimposed fixed rules, regulations or procedures that restrict authority or mandate information disclosure)." ${ }^{\text {"99 }}$ Formal accountability

\footnotetext{
66. Bressman, supra note 63, at 486-91 (discussing the presidential control model).

67. Id. at 506 .

68. Stephan, Accountability, supra note 46, at 684.

69. Rabinovich-Einy, supra note 22, at 261.
} 
typically occurs through an evaluation conducted by external means, such as judicial and quasi-judicial processes, ${ }^{70}$ and for that reason many examples of formal accountability can be found in the law. Although administrative law presents a more complicated authority versus accountability dilemma than the modern corporation, others, such as disputes involving prisoners and hospital staffing, offer more equivalently complicated dilemmas. The following sections briefly describe the authority versus accountability dilemmas presented in each of these contexts and explain how those competing interests are balanced in each context. Each section also evaluates whether that context presents any insights for shareholder derivative litigation.

\section{Administrative Law}

As noted above, the administrative agencies possess significant authority, but are subject to little control because the informal methods of accountability are largely ineffective. Formal accountability also appears ineffective in this context because the power of judicial review for agency actions is limited. ${ }^{71}$ Under current law's Chevron standard, courts must defer to reasonable administrative statutory interpretations that "rely upon the incumbent administration's views of wise policy ...." ${ }^{, 72}$ Thus, courts largely defer to the agency's policy choice when the authority versus accountability dilemma of administrative law is presented through litigation, but they do not always do so. ${ }^{73}$ Similar to

70. Keohane \& Nye, supra note 20, at 3-5 ("'Accountability] can also be created by rules, monitored by independent organizations and by courts.”); Rabinovich-Einy, supra note 22, at 261 (stating that external accountability "usually involves evaluation of performance and outcomes by a credible external entity (private or public) in the context of predetermined boundaries").

71. Bressman, supra note 63 , at 516 (discussing the proposition that courts give agencies "virtually unlimited discretion to choose their procedures for making general policy" (citing S.E.C. v. Chenery Corp., 332 U.S. 194 (1947))).

72. Chevron U.S.A., Inc. v. Natural Res. Def. Council, Inc., 467 U.S. 837, 865 (1984).

73. See Richard J. Pierce, Jr., Democratizing the Administrative State, 48 WM. \& MARY L. REV. 559, 604-07 (2006) (noting that courts "have begun to refuse to defer to agency interpretations of ambiguous agency rules where the rules were written in an extraordinarily open-ended manner," that courts "refuse to defer to an agency interpretation of a rule when that interpretation is announced only as a litigating position," and that "[c]ourts regularly refuse to defer to agency interpretations of ambiguous rules in the context of enforcement proceedings in which agencies seek to impose penalties on firms for violating agency rules" without adequate advance notice that such conduct would violate the rule); see also Thomas W. Merrill \& Kristin E. Hickman, Chevron's Domain, 89 GEO. L.J. 833, 915 (2001) ("The Supreme Court has consistently ruled that agency interpretations of statutes that deviate from the Court's own precedents are not entitled to Chevron deference."); id. at 836 (arguing that instead of applying Chevron, courts may apply "the multi-factoral approach to deference embodied in the Court's venerable decision in Skidmore v. Swift \& Co.," 323 U.S. 134, 140 (1944), which included such contextual factors as the expertise of the agency, the thoroughness of the agency's decision, and the agency's consistency with prior interpretations). 
the corporate context, such deference has been justified on the basis that courts lack expertise in such matters. But administrative law has not found a balancing point in judicial review of agencies' actions that is much different from the current business judgment rule approach to reviewing directors' actions. For that reason, administrative law offers no new solutions for shareholder derivative litigation.

\section{Prisoner Litigation}

An authority versus accountability dilemma similar to that presented in corporations appears in the context of prisoner litigation. Prisoners may seek redress of their grievances through litigation, which necessarily interferes with the prison administration's authority to administer their prisons and potentially increases the cost of prison administration. Prior to the Prison Litigation Reform Act (PLRA) ${ }^{74}$ a prisoner's complaint could be dismissed for failure to state a claim only if "it appears 'beyond doubt that the plaintiff can prove no set of facts in support of his claim which would entitle him to relief.", "75 Such a procedure was criticized as allowing excessive federal judicial intervention into state prison administration and increasing expenses for the states. ${ }^{76}$ In fact, prior to the PLRA, state prisoner litigation "accounted for the single largest category of civil lawsuits filed in U.S. district courts.",77 Further, these prisoner lawsuits represented the "case type with the lowest plaintiff win rate" as such plaintiffs "were successful in only $1.4 \%$ of lawsuits filed."

The PLRA sought to remedy these problems by mandating that inmates cannot initiate a lawsuit for violation of federal law unless they first have exhausted "such administrative remedies as are available."79 Thus, courts may dismiss such actions when inmates have failed to exhaust their administrative remedies. "By mandating that inmates first

74. Prison Litigation Reform Act, Pub. L. No. 104-134, §§ 801-810, 110 Stat. 1321 (1996) (codified as amended in scattered sections of the U.S.C.).

75. Eugene J. Kuzinski, The End of the Prison Law Firm?: Frivolous Inmate Litigation, Judicial Oversight, and the Prison Litigation Reform Act of 1995, 29 RUTGERS L.J. 361, 363 (1998) (quoting Haines v. Kerner, 404 U.S. 519, 520-21 (1972)).

76. Brian J. Ostrom et al., Congress, Courts and Corrections: An Empirical Perspective on the Prison Litigation Reform Act, 78 Notre DAME L. ReV. 1525, 1525-26 (2003).

77. Id. at 1525; see also Margo Schlanger, Inmate Litigation, 116 HARV. L. REV. 1555, 1557 (2003) (stating that in 1995, inmate lawsuits constituted "nearly a fifth of the federal civil docket").

78. Ostrom et al., supra note 76, at 1526.

79. 42 U.S.C. $§ 1997$ e(a) (2000); Sharon Dolovich, State Punishment and Private Prisons, 55 DUKE L.J. 437, 485 (2005) (noting that the PLRA was enacted "'primarily to curtail claims brought by prisoners" "under $\S 1983$ and placed strict limits on prisoners' access to federal courts (quoting Santana v. United States, 98 F.3d 752, 755 (3d Cir. 1996))). 
turn to more immediate and less expensive methods of resolution, there is a greater chance that simple disputes may be resolved within the prison itself, without involving the judicial process." courts "to dismiss inmate claims, either upon the court's own motion or that of a party, when the claim is 'frivolous, malicious, fails to state a claim upon which relief can be granted, or seeks monetary relief from a defendant who is immune from such relief." "81 Additionally, new pleading standards apply to prisoner lawsuits. ${ }^{82}$

The PLRA also alters the outcome of a successful prisoner lawsuit. "[T]he PLRA reforms the prospective and preliminary relief that judges may order, establishes findings upon which such relief must be based, and sets the permissible length of such relief." 83 These revised procedures seek to ensure "that federal judges will be involved in prison affairs for only so long" and only as "necessary to remedy a constitutional violation." ${ }^{\prime 4}$ The court may not grant prospective relief unless it is "narrowly drawn, extends no further than necessary to correct the violation of the Federal right, and is the least intrusive means necessary to correct the violation of the Federal right." ${ }^{85}$ In doing so, the court also must give "substantial weight to any adverse impact upon public safety or the operation of a criminal justice system caused by the relief." 86

The PLRA achieved its purpose, as "forty-three percent fewer inmate-initiated complaints were filed in 2001 than in 1995, despite the fact that the actual inmate population had increased by twenty-three percent in the same time period." 87 The PLRA's attempt to lessen judicial interference with prison administration, however, has received its fair share of criticism for creating the wrong balance between authority and accountability. ${ }^{88}$ Prisoner grievance procedures can be understood

80. Kuzinski, supra note 75 , at 381 .

81. Id. (quoting 42 U.S.C. $\S 1997 \mathrm{e}(\mathrm{c})(1)$ ).

82. For instance, an inmate cannot file a lawsuit for mental or emotional injury unless they can also show physical injury. 42 U.S.C. $\S 1997 \mathrm{e}(\mathrm{e})$, unconstitutional as applied by Siggers-El v. Barlow, 433 F. Supp. 2d 811, 813 (E.D. Mich. 2006).

83. Kuzinski, supra note 75 , at 376.

84. Id.

85. 18 U.S.C. $§ 3626(a)(1)(A)(2000)$

86. Id.

87. Geraldine Doetzer, Hard Labor: The Legal Implications of Shackling Female Inmates During Pregnancy and Childbirth, 14 WM. \& MARY J. WOMEN \& L. 363, 376 (2008) (citing Margo Schlanger, Inmate Litigation, 116 HARV. L. REV. 1555, at 1559-60 (2003)).

88. See generally Adam Slutsky, Totally Exhausted: Why a Strict Interpretation of 42 U.S.C. $\S$ 1997e(a) Unduly Burdens Courts and Prisoners, 73 ForDHAM L. REV. 2289 (2005); David M. Adlerstein, Note, In Need of Correction: The "Iron Triangle" of the Prison Litigation Reform Act, 101 Colum. L. REV. 1681 (2001). 
as creating a balance between three competing goals: (1) prison administrators' authority to autonomously operate prisons, (2) the containment of costs attributable to prison administration, and (3) the institution of "effective procedural conduits for the protection of prisoners' rights . . .." 89 The PLRA has been criticized as "overvalu[ing] autonomy and cost control at the expense of prisoners' rights, ${ }^{\prime 90}$ or in other words, the PLRA overvalues authority at the expense of accountability. One critic proposes that increased transparency of "grievance procedures would foster greater accountability at modest cost, without unduly interfering with the task of prison administration." 91

Prisoner litigation does not appear to offer a close analogy to corporations. Prison administrators have absolute authority over prisoners, and can only be held accountable through litigation. Prisoners have no other means of holding prison administrators accountable for their decisions. By contrast, directors do not have absolute power over corporations. Shareholders must approve certain corporate actions and shareholders can theoretically hold directors accountable through means other than litigation. However, the resolution of the authority versus accountability dilemma in prisoner litigation may present some useful insights for shareholder derivative litigation. The authority of prison administrators can be challenged only through litigation, but such litigation is governed by procedural rules designed to ensure prison administrators' authority is not disturbed except in egregious circumstances and then only after prison administrators first have had the opportunity to resolve the problem. Thus, if the balance of authority and accountability needs to be weighted more toward directors' authority in the context of shareholder derivative litigation, the procedural rules of the PLRA may offer methods for doing so.

\section{Hospital Staff Privileges}

Another interesting example of the difficulty of balancing authority and accountability can be found in the area of hospital-staffing decisions. At first blush, the balance appears to be heavily tilted toward authority, because the general rule is that a private hospital may control its staffing procedures without court interference in such business decisions. ${ }^{92}$

\footnotetext{
89. Adlerstein, supra note 88 , at 1683 .

90. Id.

91. Id. at 1697 .

92. Katharine Van Tassel, Hospital Peer Review Standards and Due Process: Moving From Tort Doctrine Toward Contract Principles Based on Clinical Practice Guidelines, 36 SETON HALL
} 
However, an exception exists when the decision involves the revocation, suspension, or reduction of existing staff privileges in private hospitals that are quasi-public or constitute a virtual monopoly in a particular area. $^{93}$ In such cases, courts must accord great deference to hospitals' decisions regarding staff privileges, and judicial review is limited to factors which are within the expertise of courts. ${ }^{94}$ Judicial review, however, is allowed to determine that the hospital complied with its bylaws and to ensure the hospital's bylaws afforded staff basic notice and fair hearing procedures. ${ }^{95}$ Further, a court may review a private hospital's actions even where the bylaws have been followed if actual unfairness on the part of the hospital, its committees, or individual members of the committees has been demonstrated in the record. ${ }^{96}$ In such cases, judicial review of hospital decisions regarding staff procedures and privileges has included a determination that the decision was "made in good faith and on objectively reasonable grounds," the decision was "consistent with the public interest," and the decision was "supported by sufficient evidence."

In sum, the balance in this context appears weighted toward accountability, despite statements that the courts may not substitute their judgment for that of hospitals, because courts have held that they can review staff decisions on such broad notions as good faith, reasonableness, unfairness, and sufficient evidence. Litigation challenging hospitals' decisions regarding staff privileges resembles shareholder derivative litigation challenging directors' decisions. In both circumstances, courts have recognized that such decisions are business decisions within the defendants' discretion and that deference should be given to the defendants. Further, in both contexts, courts can potentially exercise broad judicial review, although arguably courts are conducting more searching review of hospitals' decisions when they review decisions regarding staff privileges for objectively reasonable grounds consistent with public interest. If a normative judgment is made that judicial review of directors' decisions should be broader than current law permits, this analogy may offer a way to do so.

L. REV. 1179, 1215 (2006).

93. See Kevin M. McKenna, Courts Leave Legislatures to Decide the Fate of the NCAA in Providing Due Process, 2 SETON HALl J. SPORT L. 77, 113 (1992) (stating an Illinois exception to the rule of non-review where a "hospital must follow its own bylaws" when revoking or reducing staff privileges or "be subject to limited judicial review").

94. See Van Tassel, supra note 92, at 1201.

95. 41 C.J.S. Hospitals § 32 (2008).

96. Adkins v. Sarah Bush Lincoln Health Ctr., 544 N.E.2d 733, 738 (Ill. 1989).

97. 41 C.J.S. Hospitals $§ 32$ (2008). 


\section{BALANCING AUTHORITY AND ACCOUNTABILITY IN SHAREHOLDER DERIVATIVE LITIGATION}

Shareholder derivative litigation constitutes the formal method of accountability in the corporate context. In that context, the business judgment rule currently functions as the mechanism that balances directors' authority against shareholders' right to hold directors accountable. In corporate law, authority and accountability are competing powers that are in tension, because more of one means less of the other. ${ }^{98}$ Nobel laureate economist Kenneth Arrow described the crux of this authority versus accountability dilemma when he explained that "the power to hold to account is ultimately the power to decide." 99 This idea has led a corporate scholar to argue that "efforts to hold the board accountable necessarily shift some of the board's decision-making authority to shareholders or judges." ${ }^{100}$ Correspondingly, efforts to insulate the board from legal liability necessarily increase the board's authority while decreasing shareholders' ability to hold directors accountable. The question is how best to balance authority and accountability within the context of shareholder derivative litigation. Section A explains the current formulation of the business judgment rule in balancing authority and accountability in such litigation. Section B then examines proposals to shift the balance toward accountability, while Section $\mathrm{C}$ analyzes proposals to shift the balance toward authority.

\section{A. The Business Judgment Rule}

The business judgment rule is one of the most controversial and least understood doctrines of corporate law. ${ }^{101}$ It has received extensive

98. Bainbridge, supra note 12 , at 86,108 . The tension between authority and accountability can be seen not only in the director primacy model, but also in the shareholder primacy model of corporate governance. See, e.g., Lucian Arye Bebchuk, The Case for Increasing Shareholder Power, 118 HARV. L. REV. 833, 875 (2005) (advocating for more accountability); Jill E. Fisch, Measuring Efficiency in Corporate Law: The Role of Shareholder Primacy, 31 J. CORP. L. 637, 66263 (2006) (discussing fiduciary duties as a method of accountability); Henry Hansmann \& Reinier Kraakman, The End of History for Corporate Law, 89 GEO. L.J. 439, 441, 444-49 (2001) (discussing the shareholder primacy model, as well as the manager-oriented model, the labororiented model, and the state-oriented model).

99. Bainbridge, supra note 12, at 103, 108 (citing KENNETH J. ARROW, THE Limits OF ORGANIZATION 78 (1974)).

100. Id. at 103-04.

101. See S. Samuel Arsht, The Business Judgment Rule Revisited, 8 HofSTRA L. REV. 93,93 (1979) (stating the business judgment rule is misunderstood); Bainbridge, supra note 12, at 83-84 ("Countless cases invoke it and countless scholars have analyzed it. Yet, despite all of the attention lavished on it, the business judgment rule remains poorly understood."); Douglas M. Branson, 
debate among scholars, practitioners, and judges as to its proper formulation and application. ${ }^{102}$ Yet no satisfying framework for understanding and applying the business judgment rule has developed. ${ }^{103}$

The business judgment rule has existed in American corporate law for almost two centuries. ${ }^{104}$ Developed through common law, it generally protects directors from liability for their decisions when challenged by shareholders through derivative litigation. Judges and scholars have advanced many rationales for the business judgment rule: preventing shareholders from second-guessing directors' decisions with the benefit of hindsight, ${ }^{105}$ protecting directors from liability "for honest mistakes of judgment or unpopular business decisions," directors to take calculated business risks, ${ }^{107}$ providing protection to

Lecture, The Rule That Isn't A Rule-The Business Judgment Rule, 36 VAL. U. L. REV. 631, 631 (2002) (stating the business judgment rule is "much misunderstood"); Lyman P.Q. Johnson, Corporate Officers and the Business Judgment Rule, 60 Bus. LAw. 439, 454 (2005) ("Manne's statement about the rule remains as true in 2005 as when first made in 1967: the business judgment rule is 'one of the least understood concepts in the entire corporate field."'); Henry G. Manne, Our Two Corporation Systems: Law and Economics, 53 VA. L. REV. 259, 270 (1967) (stating the business judgment rule is "one of the least understood concepts in the entire corporate field").

102. See, e.g., Kenneth B. Davis, Jr., Once More, the Business Judgment Rule, 2000 WIs. L. REV. 573, 573 (2000) (noting that "thousands of pages of corporate law scholarship and commentary have been devoted to [the business judgment rule], yet we remain short of any broad consensus as to [its rationale]"); Johnson, supra note 101, at 454 (recognizing that there is "deep rooted disagreement about the basic purpose and thrust of the business judgment rule" and the "degree of deference that courts ... should accord director judgments"); Dana M. Muir \& Cindy A. Schipani, Fiduciary Constraints: Correlating Obligation with Liability, 42 WAKE FOREST L. REV. 697, 726 (2007) (stating that confusion of the business judgment rule "stems from the issue of whether [the Rule] is simply a doctrine that prevents courts from second-guessing good faith business decisions or whether it is a standard of care"); Bernard S. Sharfman, Being Informed Does Matter: Fine Tuning Gross Negligence Twenty Plus Years After Van Gorkom, 62 Bus. LAw. 135, 143 (2006) (stating the business judgment rule is a misunderstood legal doctrine because of the inability to appreciate the mechanics of the rule).

103. See Franklin A. Gevurtz, The Business Judgment Rule: Meaningless Verbiage or Misguided Notion?, 67 S. CAL. L. REV. 287, 287-88 (1994) (stating that "[a]t first glance, the general concept behind the [business judgment] rule seems unassailable" but that "a problem occurs when courts and writers attempt to inject specific content into this general proposition-immediately, a lack of consensus emerges as to what the rule really is").

104. See Arsht, supra note 101, at 93 (dating the business judgment rule to at least the early 1800s).

105. See A.L.I., Principles of CoRPorate Governance: ANAlysis AND ReCOMMENDATIONS $\S 4.01 \mathrm{cmt}$. d (1994) (stating the business judgment rule protects directors "from the risks inherent in hindsight reviews of their unsuccessful decisions" and avoids "stifling innovation and venturesome business activity").

106. Arsht, supra note 101, at 96; see also Bainbridge, supra note 12, at 113-14 ("Business decisions rarely involve black-and-white issues; instead, they typically involve prudential judgments among a number of plausible alternatives. Given the vagaries of business, moreover, even carefully made choices among such alternatives may turn out badly.").

107. See Bainbridge, supra note 12, at 110 (stating that encouraging risk taking is a justification for the business judgment rule); Branson, supra note 101, at 632 (stating the business judgment rule is "built upon economic freedom and the encouragement of informed risk taking"); see also Muir \& 
ensure that individuals will be willing to serve as directors, ${ }^{108}$ and recognizing that directors are better-suited than courts to make business decisions. ${ }^{109}$ The real difficulty lies not in understanding why the business judgment rule exists, but in determining how courts should apply the protections of the business judgment rule.

Under any formulation of the business judgment rule, it operates as a defense asserted in shareholder derivative actions that challenge a decision made by a corporation's board of directors. ${ }^{110}$ Procedurally, defendants have been allowed to assert their business judgment defense on a motion to dismiss, a motion for summary judgment, and at trial. ${ }^{111}$ To understand how courts decide whether the business judgment defense should protect the directors' decision, one must look to the Delaware courts, which are the undisputed leaders in the development of corporate common law now ${ }^{112}$ and for the foreseeable future. ${ }^{113}$

In recent years, Delaware courts have consistently articulated that the business judgment rule operates as a presumption that directors have

Schipani, supra note 102, at 726 (arguing that without the business judgment rule, directors would approve only low-risk projects even when high-risk projects may be better decisions).

108. See Arsht, supra note 101, at 97 ("The business judgment rule grew principally from the judicial concern that persons of reason, intellect, and integrity would not serve as directors if the law exacted from them a degree of prescience not possessed by people of ordinary knowledge."); R. Franklin Balotti \& Mark J. Gentile, Commentary from the Bar, Elimination or Limitation of Director Liability for Delaware Corporations, 12 DEL. J. CORP. L. 5, 9 (1987) ("The general result has been that many qualified individuals have refused to serve as directors."); Muir \& Schipani, supra note 102 , at 726 (arguing that without the business judgment rule, corporations would have problems attracting qualified members to serve on boards).

109. See Dodge v. Ford Motor Co., 170 N.W. 668, 684 (Mich. 1919) ("The judges are not business experts."); Branson, supra note 101, at 637 (stating "courts are ill-equipped to review business decisions" because they "often involve intangibles, intuitive insights or surmises as to business matters such as competitive outlook, cost structure, and economic and industry trends" and are "not susceptible to systematic analysis").

110. See In re The Walt Disney Co. Derivative Litig., 906 A.2d 27, 52 (Del. 2006).

111. See In re BHC Commc'ns, Inc. S'holder Litig., 789 A.2d 1, 4 (Del. Ch. 2001) (“[I]t is a bedrock principle of Delaware corporate law that, where a claim for breach of fiduciary duty fails to contain allegations of fact that, if true, would rebut the presumption of the business judgment rule, that claim should ordinarily be dismissed under Rule 12(b)(6)."); Weinberger v. United Fin. Corp. of Cal., No. 5915 (1979), 1983 WL 20290, at*6 (Del. Ch. Oct. 13, 1983) (noting that to defeat a summary judgment motion, plaintiff can "allude to facts in the record which are undisputed or which are disputed but, if true, are sufficient to rebut the presumption" of the business judgment rule); In re The Walt Disney Co. Derivative Litig., 907 A.2d 693, 697 (Del. Ch. 2005) (holding defendants were entitled to business judgment rule protection after a lengthy trial).

112. See William H. Rehnquist, The Prominence of the Delaware Court of Chancery in the State-Federal Joint Venture of Providing Justice, 48 BUS. LAw. 351, 354 (1992) (describing Delaware's preeminence in corporate law); see also Veasey, supra note 1, at 443 ("Delaware law is the default repository for the rich and comprehensive common law of fiduciary duty of directors .....").

113. See Jill E. Fisch, The Peculiar Role of the Delaware Courts in the Competition for Corporate Charters, 68 U. CIN. L. REv. 1061, 1061-64 (2000). 
acted in accordance with their fiduciary duties in making decisions for the corporation. ${ }^{114}$ The plaintiff-shareholders may rebut that presumption by showing that the defendant-directors violated any one of their fiduciary duties or by showing that the business judgment rule is inapplicable because the defendant-directors committed an act of fraud, illegality, or waste. ${ }^{115}$ If the plaintiff-shareholders fail to rebut the presumption, then the business judgment rule protects the defendantdirectors from liability for their decision. ${ }^{116}$ On the other hand, if the plaintiff-shareholders show a breach of a fiduciary duty or show fraud, illegality, or waste, then the presumption of the business judgment rule is rebutted and the defendant-directors must prove that the challenged transaction was "entirely fair" to the corporation and its shareholders. ${ }^{117}$ Even this statement of the current formulation of the business judgment rule does not present a complete explanation. As this author has argued elsewhere, the Delaware courts now apply stricter scrutiny to directors' pre-trial assertions of the business judgment rule defense in shareholder derivative actions, although without explicitly altering the current formulation of that defense. ${ }^{118}$

114. See In re Walt Disney, 906 A.2d at 52 (quoting Aronson v. Lewis, 473 A.2d 805, 812 (Del. 1984)) ("Our law presumes that 'in making a business decision the directors of a corporation acted on an informed basis, in good faith, and in the honest belief that the action taken was in the best interests of the company.' Those presumptions can be rebutted if the plaintiff shows that the directors breached their fiduciary duty of care or loyalty or acted in bad faith. If that is shown, the burden then shifts to the director defendants to demonstrate that the challenged act or transaction was entirely fair to the corporation and its shareholders."); see also McMullin v. Beran, 765 A.2d 910, 917 (Del. 2000) ("Procedurally, the initial burden is on the shareholder plaintiff to rebut the presumption of the business judgment rule. To meet that burden, the shareholder plaintiff must effectively provide evidence that the defendant board of directors, in reaching its challenged decision, breached any one of its 'triad of fiduciary duties, loyalty, good faith or due care.' Substantively, 'if the shareholder plaintiff fails to meet that evidentiary burden, the business judgment rule attaches' and operates to protect the individual director-defendants from personal liability for making the board decision at issue.”). But see R. Franklin Balotti \& James J. Hanks, Jr., Rejudging the Business Judgment Rule, 48 Bus. LAw. 1337, 1345 (1993) (arguing the business judgment rule is not a presumption "in the strict evidentiary sense of the term").

115. See In re Walt Disney, 906 A.2d at 73-75 (analyzing an allegation of waste separately from the alleged breaches of fiduciary duties); see also Paglin v. Saztec Int'l, Inc., 834 F. Supp. 1184, 1200 (W.D. Mo. 1993) (noting "[t]he business judgment rule does not apply when the act complained of is ultra vires, illegal, or fraudulent"); Shlensky v. Wrigley, 237 N.E.2d 776, 779 (Ill. App. Ct. 1968) ("“The directors are chosen to pass upon [questions of policy and business management] and their judgment unless shown to be tainted with fraud is accepted as final."” (quoting Davis v. Louisville Gas \& Elec. Co., 142 A. 654 (Del. Ch. 1928))); Kamin v. Am. Express Co., 383 N.Y.S.2d 807, 810-11 (N.Y. Sup. Ct. 1976) (noting courts will not substitute their judgment for that of directors absent "fraud, dishonesty, or nonfeasance").

116. Citron v. Fairchild Camera \& Instrument Corp., 569 A.2d 53, 64 (Del. 1989).

117. In re Walt Disney, 906 A.2d at 52; Emerald Partners v. Berlin, 787 A.2d 85, $90-91$ (Del. 2001); Cede \& Co. v. Technicolor, Inc., 634 A.2d 345, 361 (Del. 1993); Aronson v. Lewis, 473 A.2d 805, 812 (Del. 1984), overruled on other grounds by Brehm v. Eisner, 746 A.2d 244 (Del. 2000).

118. See Scarlett, supra note 3, at 603-09. 


\section{B. Shifting the Balance Toward Accountability}

Scholars have made several proposals that would alter shareholder derivative litigation by shifting the balance more toward accountability. Perhaps the most dramatic example is Professor Gevurtz's proposal to abolish the business judgment rule. ${ }^{119} \mathrm{He}$ reviewed the various formulations that courts have given to the business judgment rule over time, and concluded that the business judgment rule's various meanings could be broken into two categories. ${ }^{120} \mathrm{He}$ characterized the first category as "meaningless" because it is "simply saying that directors will not be liable for their decisions unless there is a reason for holding them liable," such as if they breach their duties of care or loyalty. ${ }^{121}$ He called the second category "misguided" because it establishes a special standard of liability - gross negligence - for alleged duty of care breaches that differs from typical tort law. ${ }^{122}$ Professor Gevurtz concluded that courts should apply the ordinary negligence standard to review directors' actions, ${ }^{123}$ because directors should be held to "the same rules of negligence as everyone else." 124 Thus, he advocated for the abolition of the business judgment rule, because "it is a phrase of limited utility and much potential for mischief." 125 Another scholar has advocated abolishing the business judgment rule in the tender offer context. ${ }^{126}$

Taking a slightly different tact, other scholars advocate for broader judicial review of directors' decisions through various expansions of the fiduciary duties which thereby alter the application of the business judgment rule. For instance, some scholars assert that directors owe a fiduciary duty of good faith and that a breach of that duty should

119. Gevurtz, supra note 103, at 287-89 ("This Article therefore concludes that the rule should be abolished and directors be required to live with the same rules of negligence as everyone else.").

120. Id. at 290 .

121. Id. at 289-91.

122. Id. at 289, 295-303 (identifying the "misguided" category as including three standards taken by courts and commentators: (1) "the good faith standard," which focuses on directors' "subjective motivations"; (2) "the gross negligence standard," which "entails some worse level of dereliction than ordinary negligence"; and (3) "the process-versus-substance distinction," which calls for more scrutiny of process and limits, but does not eliminate judicial scrutiny of the decision's merits).

123. Id. at $336-37$.

124. Id. at 289 .

125. Id. at 336-37 (advocating for abolishing the business judgment rule and holding directors to the typical negligence standards); $i d$. at 337 (stating that 'the business judgment 'rule' is a rule which corporate law would well do without").

126. Matthew Taylor, Tender Offers and the Business Judgment Rule, 7 U. MIAMI BUS. L. REV. 171, 190 (1998) (proposing that the business judgment rule be abolished in the tender offer context). 
overcome the business judgment rule presumption. ${ }^{127}$ Because of the nature of good faith, courts reviewing allegations that directors breached that duty must necessarily look into the subjective intentions of directors. ${ }^{128}$ Correspondingly, courts likely cannot decide whether directors have breached a duty of good faith on a motion to dismiss or a motion for summary judgment, because such a decision necessarily entails a review of the facts. The Delaware Supreme Court recently has suggested that directors may owe at least a limited duty of good faith and that directors' acts of bad faith may rebut the business judgment rule presumption in some circumstances. ${ }^{129}$

Some scholars similarly advocate for broader judicial review by proposing an expansion of the duty of loyalty. Under current common law, directors must be disinterested and independent in voting on transactions. ${ }^{130}$ However, courts have traditionally accepted only familial relationships as destroying a director's independence, ${ }^{131}$ holding that "[a]llegations of mere personal friendship or a mere outside business relationship, standing alone, are insufficient to raise a reasonable doubt about a director's independence." 132 For example, allegations that

127. See, e.g., Hillary A. Sale, Delaware's Good Faith, 89 CORNELl L. REV. 456, 483-84 (2004).

128. Gevurtz, supra note 103, at 297.

129. Compare In re The Walt Disney Co. Derivative Litig., 906 A.2d 27, 52, 63 (Del. 2006) ("Those presumptions can be rebutted if the plaintiff shows that the directors breached their fiduciary [duties] or acted in bad faith."), with Stone v. Ritter, 911 A.2d 362, 369-70 (Del. 2006) ("a showing of bad faith conduct ... is essential to establish director oversight liability"); see Scarlett, supra note 3, at 619-22 (discussing In re Walt Disney and Stone v. Ritter).

130. See Cede \& Co. v. Technicolor, Inc., 634 A.2d 345, 362 (Del. 1993); see also Schoon v. Smith, 953 A.2d 196, 207 (Del. 2008) ("The requirement of director independence [inheres] in the conception and rationale of the business judgment rule.... Independence means that a director's decision is based on the corporate merits of the subject before the board rather than extraneous considerations or influences." (quoting Aronson v. Lewis, 473 A.2d 805, 816 (Del. 1984), overruled on other grounds by Brehm v. Eisner, 746 A.2d 244, 254 (Del. 2000))); Orman v. Cullman, 794 A.2d 5, 22 (Del. Ch. 2002) (stating the business judgment rule is rebutted where a majority of the directors either were "interested in the outcome of the transaction or lacked the independence to consider objectively whether the transaction was in the best interest of its company and all of its shareholders").

131. See, e.g., Telxon Corp. v. Meyerson, 802 A.2d 257, 264 (Del. 2002) (noting that while a director may be controlled in multiple ways, "independence" focuses on familial or close personal relationships).

132. Beam v. Stewart, 845 A.2d 1040, 1050 (Del. 2004); Crescent/Mach I Partners, L.P. v. Turner, 846 A.2d 963, 980-81 (Del. Ch. 2000) (finding allegation that a director was controlled by another director because of their 15-year professional and personal relationship was insufficient to raise a reasonable doubt as to independence); Benerofe v. Cha, No. 14614, 1998 WL 83081, at *3 (Del. Ch. Feb. 20, 1998) (finding conclusory allegations of long-standing friendship is not enough to raise a reasonable doubt that a director could exercise his independent business judgment); In re Grace Energy Corp. S'holders Litig., No. 12,464, 1992 WL 145001, at*4 (Del. Ch. June 26, 1992) ("[T]he Delaware Supreme Court has made it clear that conclusory allegations of such personal affinity alone are not sufficient to establish director interest. Actual financial interest must be 
Martha Stewart and other directors "moved in the same social circles, attended the same weddings, developed business relationships before joining the board, and described each other as 'friends,' even when coupled with Stewart's 94\% voting power, [were] insufficient, without more, to rebut the presumption of independence." 133 Similarly, alleging that a director is controlled or dominated by another director almost never succeeds in court. ${ }^{134}$ Criticizing such reasoning, some scholars argue that courts should apply a broader notion of independence when reviewing alleged breaches of the duty of loyalty. ${ }^{135}$ Similar to the duty of good faith, however, such expansion of the duty of loyalty would likely require a more fact-intensive review of the subjective relationships between directors.

Finally, others advocate for changes to judicial review of alleged violations of the duty of care. For instance, some endorse courts' substantive review of directors' decisions. ${ }^{136}$ Although courts frequently state that they review only the process and procedures used by directors in making a decision, ${ }^{137}$ some court opinions arguably permit review of the substance of directors' decisions. For instance, some opinions state that courts may review directors' decisions for "rationality" or "irrationality." 138 A due care analysis that allows a merit-based review

shown.").

133. Beam, 845 A.2d at 1051 (analyzing the directors' independence and the business judgment rule's applicability in the context of deciding whether demand was excused).

134. See Branson, supra note 101, at 642 ("A plaintiff making [a dominated director case] faces an uphill battle. Courts are loathe to find that an otherwise reputable business person is not his or her own person."); see also Beam, 845 A.2d at 1052 ("To create a reasonable doubt about an outside director's independence, a plaintiff must plead facts that would support the inference that because of the nature of a relationship or additional circumstances other than the interested director's stock ownership or voting power, the non-interested director would be more willing to risk his or her reputation than risk the relationship with the interested director.").

135. See, e.g., Lisa M. Fairfax, Spare the Rod, Spoil the Director? Revitalizing Directors' Fiduciary Duty through Legal Liability, 42 Hous. L. REV. 393 (2005); Julian Velasco, Structural Bias and the Need for Substantive Review, 82 WASH. U. L.Q. 821 (2004).

136. See, e.g., Julian Velasco, Taking Shareholder Rights Seriously, 41 U.C. DAVIS L. REV. 605 (2007); Melvin A. Eisenberg, The Duty of Care of Corporate Directors and Officers, 51 U. PITT. L. REV. 945 (1990).

137. See Brehm v. Eisner, 746 A.2d 244, 262-64 (Del. 2000) (holding the business judgment rule requires "process due care"); see also Smith v. Van Gorkom, 488 A.2d 858, 874-88 (Del. 1985) (reviewing the process by which the directors made their decision), superseded by statute as stated in Emerald Partners v. Berlin, 787 A.2d 85 (Del. 2001); Underbrink v. Warrior Energy Servs. Corp., No. 2982-VCP, 2008 WL 2262316, at*10 (Del. Ch. May 30, 2008) ("Courts give deference to directors' decisions reached by a proper process, and do not apply an objective reasonableness test in such a case to examine the wisdom of the decision itself." (quoting Brazen v. Bell Atl. Corp., 695 A.2d 43, 49 (Del. 1997))).

138. See In re The Walt Disney Co. Derivative Litig., 906 A.2d 27, 74 (Del. 2006); see also Brehm v. Eisner, 746 A.2d 244, 264 (Del. 2000) ("Irrationality is the outer limit of the business judgment rule.”); AC Acquisitions Corp. v. Anderson, Clayton \& Co., 519 A.2d 103, 111 n.9 (Del. 
presents an obvious opportunity for shareholders and courts to secondguess directors' decisions with the benefit of hindsight bias. Further, allowing a substantive review of directors' decisions almost guarantees that courts will find a factual question as to whether the duty of care was breached, which will prevent dismissal or summary judgment. Some scholars urge a slightly different alteration of the duty of care, advocating for courts to review alleged breaches of the duty of care under the typical "ordinary negligence" standard rather than the "gross negligence" standard used by some courts. ${ }^{139}$ Lowering the standard to ordinary negligence would likely make it easier for shareholders to overcome the business judgment rule presumption, as the gross negligence standard implies a greater degree of negligence is required to overcome that presumption.

Professor Gevurtz's 1994 proposal to abolish the business judgment rule has gone nowhere. And although proposals to broaden judicial review through expansion of the fiduciary duties abound, they have yet to gain any traction in the courts or legislatures. These proposals, however, signal that more, not less, accountability is sought by many scholars and perhaps by shareholders.

\section{Shifting the Balance Toward Authority}

By contrast, the balance between authority and accountability could be weighted toward authority. The most extreme example would likely be a proposal to eliminate shareholder derivative litigation altogether. Because shareholders have other methods of holding directors accountable, such as the informal accountability mechanisms discussed in Part II.A., one could argue that eliminating (or even lessening) the accountability available through shareholder derivative litigation does not harm shareholders overall. No scholar, however, has advocated completely eliminating shareholder derivative litigation, although some

Ch. 1986) ("[A] decision by disinterested directors following a deliberative process may still be the basis for liability if such decision cannot be 'attributed to any rational business purpose,' ... or is 'egregious."” (quoting Sinclair Oil Corp. v. Levien, 280 A.2d 717, 720 (Del. 1971) and Aronson v. Lewis, 473 A.2d 805, 815 (Del. 2004))).

139. See, e.g., Gevurtz, supra note 103, at 289 (citing Smith v. Van Gorkom, 488 A.2d 858, 872 (Del. 1985) as representative, because the court stated that the directors may be held liable for breaching their duty of care if the plaintiff shows that the directors were "grossly negligent" in failing to inform themselves of all material information reasonably available to them); Philip C. Sorensen, Discretion and Its Limits-An Analytical Framework for Understanding and Applying the Duty of Care to Corporate Directors (and Others), 66 WASH. U. L.Q. 553 (1988). 
have advocated that such disputes could be resolved through quasijudicial means such as arbitration rather than through the courts. ${ }^{140}$

Giving directors complete control and then making it impossible to sanction them seems dangerous. After all, as the old adage says, absolute power corrupts absolutely. ${ }^{141}$ Even a corporate scholar advocating that the balance should be shifted more toward authority recognizes that "unaccountable authority is likely to make unnecessary errors" and that "unaccountable authority may be exercised opportunistically." 142 That opportunism includes not only "intentional self-dealing," but also "forms of shirking" such as "negligence, oversight, incapacity, and even honest mistakes." "143 Thus, litigation still presents an important accountability mechanism for shareholders.

Yet the current formulation of the business judgment rule has been criticized for "treating the business judgment rule as a substantive doctrine, expressing the scope of director liability, and permitting courts some room to examine the substantive merits of the board's decision." Because the current approach permits the business judgment rule to be rebutted if the plaintiff can show a breach of the duty of due care, one critic argues it "puts the cart before the horse," because "[d]irectors who violate their duty of care do not get the protections of the business judgment rule." ${ }^{145}$ Some critics also argue that the current business judgment rule approach "merely assigns to the plaintiff the burden of establishing a prima facie case - the same burden the plaintiff bears in all civil litigation." 146 In other words, the current approach makes the rule

140. See Andrew J. Sockol, Comment, A Natural Evolution: Compulsory Arbitration of Shareholder Derivative Suits in Publicly Traded Corporations, 77 Tul. L. REV. 1095, 1108 (2003); see also Scott R. Haiber, The Economics of Arbitrating Shareholder Derivative Actions, 4 DEPAUL Bus. L.J. 85, 85 (1991).

141. Letter from John Emerich Edward Dalberg Acton to Bishop Mandell Creighton (1887), http://www.phrases.org.uk/meanings/288200.html (last visited Oct. 5, 2008).

142. Bainbridge, supra note 12, at 107.

143. Id. at 108 .

144. Id. at 87 ; see also id. at 102 (arguing that the current approach expands the scope of judicial review by encouraging judges to evaluate not only the directors' decision-making process "but also the substance of the directors' decision").

145. Id. at 94-95. In other words, "the whole point of the business judgment rule is to prevent courts from even asking the question: did the board breach its duty of care?" Id. at 95; see also id. at 100 ("One does not rebut the business judgment rule by showing a breach of the duty of care; if the business judgment rule applies, the court will not review the directors' conduct to see if that duty was violated.").

146. Id. at 100; see also Gevurtz, supra note 103, at 292 ("This 'presumption' entails nothing more than saying that the plaintiff who challenges a decision of the board has the burden of proving that the directors breached one of their duties. Yet, the proposition that the plaintiff, in any context, has the burden of proving his or her prima facie case is a rule with which every first-year law student should be familiar."). 
nothing more than a restatement of the principle that a defendant is entitled to summary judgment when the plaintiff fails to prove his prima facie case. ${ }^{147}$ One scholar hypothesizes that the current approach allows more shareholder derivative actions to overcome motions to dismiss, ${ }^{148}$ and thus the number of such actions that are initiated will increase as will the potential settlement value of those actions. ${ }^{149}$ Despite these criticisms, the Delaware Supreme Court has reaffirmed the current formulation of the business judgment rule. ${ }^{150}$

Professor Bainbridge has recently advocated for shifting the balance more toward authority, by proposing that courts view the business judgment rule as a doctrine of abstention. ${ }^{151}$ This proposal has gained momentum as other corporate scholars have endorsed the proposed abstention approach to the business judgment rule, ${ }^{152}$ and others have urged a similar non-review approach. ${ }^{153}$ However, no one has critically

147. Bainbridge, supra note 12, at 101 ("If the plaintiff fails to carry that burden, the business judgment rule requires the court to dismiss the lawsuit without inquiry into the merits of the decision.").

148. Id.

149. Id.

150. See, e.g., In re The Walt Disney Co. Derivative Litig., 906 A.2d 27, 52, $73-75$ (Del. 2006); In re Transkaryotic Therapies, Inc., 954 A.2d 346, 363 (Del. Ch. 2008); Underbrink v. Warrior Energy Servs. Corp., No. 2982-VCP, 2008 WL 2262316, at*10 (Del. Ch. May 30, 2008).

151. Bainbridge, supra note 12 , at 87.

152. See Andrew S. Gold, A Decision Theory Approach to the Business Judgment Rule: Reflections on Disney, Good Faith, and Judicial Uncertainty, 66 MD. L. REV. 398, 401 (2007) (adopting the abstention theory and noting that in practice the business judgment rule carves out a "large swath of director conduct which is unreviewable by the judicial system, unless plaintiffs can demonstrate a conflict of interest or that the board's conduct is so irrational that it could not have been motivated by a legitimate business purpose"); Steven E. Seward, A World of Evergreen Fees? In re Pan American Hospital and Evergreen Retainers in Chapter 11 Reorganizations, 60 U. MIAMI L. REV. 399, 401 (2006) (stating the business judgment rule is a doctrine of abstention, preventing courts from inquiring into the wisdom of a board's decision-making, provided the board complies with basic procedural requirements); Jeremy Telman, The Business Judgment Rule, Disclosure, and Executive Compensation, 81 TUL. L. REV. 829, 830-33 (2007) (advocating that the business judgment rule "be aggressively conceived as a doctrine of abstention" and application of the rule be limited to "cases where disclosure of the decision-making process involved in the challenged business decision would require disclosure of prospective business plans"); id. at 832 (stating the abstention doctrine is "[t]he most compelling explanation of how the Rule ought to be conceptualized" as it protects corporations from suits challenging substantive decisions that are within the scope of board control); see also Elizabeth A. Nowicki, A Director's Good Faith, 55 BUFF. L. REV. 457, 534 (2007) (referring to a presumption of judicial abstention from substantive review of directors' decisions); Fred W. Triem, Judicial Schizophrenia In Corporate Law: Confusing the Standard of Care with the Business Judgment Rule, 24 AlaSKa L. REV. 23, 27 (2007) (stating the business judgment rule supplies "judicial restraint and abstention" and furnishes a "deferential standard of review by which courts will abstain from second guessing the directors' business decisions").

153. See Branson, supra note 101, at 631 (arguing the business judgment rule should be a standard of non-review); Sharfman, supra note 102, at 145 (arguing the business judgment rule is not a standard of liability, but rather a standard of non-review). 
analyzed Professor Bainbridge's proposal nor examined its actual application in shareholder derivative litigation. Following Section 1's explanation of the proposed abstention approach to the business judgment rule, Section 2 will remedy that deficit.

\section{An Abstention Approach to the Business Judgment Rule}

As framed by Professor Bainbridge, "the [business judgment] rule is better understood as a doctrine of abstention pursuant to which courts in fact refrain from reviewing board decisions unless exacting preconditions for review are satisfied." ${ }^{154}$ The key underlying assumption for Professor Bainbridge's proposal is that the courts' current approach to the business judgment rule inadequately respects the value of directors' authoritymeaning directors' decision-making power. ${ }^{155}$

According to Professor Bainbridge, "corporate decision-making efficiency can be ensured only by preventing the board's decisionmaking authority from being trumped by courts under the guise of judicial review." 156 In his opinion, courts "must not lightly interfere with management or the board's decision-making authority in the name of accountability." 157 He claims that such abstention would protect directors from the risk of hindsight review of their decisions and avoid the risk of stifling risk-taking. ${ }^{158}$ He also justifies his abstention approach by claiming that "judges are not business experts," 159 and that judicial review can interfere with the "internal team governance structures" that govern board behavior by destroying key interpersonal relationships vital to the board's decision-making. ${ }^{160}$

Professor Bainbridge argues the business judgment rule should be viewed as a doctrine of abstention establishing a presumption against judicial review of duty of care claims. ${ }^{161}$ Under his approach, courts will

154. Bainbridge, supra note 12 , at 87 ; see also id. at 129 ("[E]xcept to verify that the relevant preconditions for review are not met, courts should simply abstain from reviewing operational decisions.").

155. Id. at 85 .

156. Id. This viewpoint arises from Professor Bainbridge's director primacy theory, which posits that the "board of directors is not an agent of the shareholders" but "rather, the board is the embodiment of the corporate principal, serving as the nexus of the various contracts making up the corporation." Id. at 85-86.

157. Id. at 109 .

158. Id. at 110 (citing AM. LAW InST., PRINCIPLES OF CORPORATE GOVERNANCE: ANALYSIS AND RECOMMENDATIONS $\S 4.01 \mathrm{cmt}$. D (1994)).

159. See id. at 117-19 (quoting Dodge v. Ford Motor Co., 170 N.W. 668, 684 (Mich. 1919)).

160. Id. at 124-26.

161. Id. at 109 . 
begin with a presumption against review and evaluate the decisionmaking process instead of the quality of the decision. ${ }^{162}$ Thus, courts following this abstention approach will abstain from reviewing the substantive merits of the directors' conduct unless the plaintiff can satisfy rigorous preconditions for review. ${ }^{163}$ Professor Bainbridge contends that if the business judgment rule is framed as a doctrine of abstention, judicial review will be the exception as opposed to the rule. ${ }^{164}$ Likewise, he claims that the abstention approach "ensures that the null hypothesis is deference to the board's authority." 165 He believes that his proposal offers a more objective approach because, when certain preconditions for review are not satisfied, courts will "abstain from reviewing operational decisions." ${ }^{\text {"166 }} \mathrm{He}$ states that abstention in operational decisions is appropriate since most such decisions do not create any tension between directors' and shareholders' interests. ${ }^{167}$

Professor Bainbridge suggests that an abstention approach to the business judgment rule "has a long pedigree in American law." "68 $\mathrm{He}$ cites the 1968 case of Shlensky $v$. Wrigley, ${ }^{169}$ as a classic expression of the business judgment rule as a doctrine of abstention. ${ }^{170}$ William Shlensky, a minority shareholder in the corporation that owned the Chicago Cubs and operated Wrigley Field, brought a shareholder derivative action alleging the corporation was losing money due to poor attendance at home games, which he argued was attributable to the board's decision not to install lights at Wrigley Field and thus not to schedule night games. ${ }^{171}$ Shlensky alleged that the directors violated their duty of care by disregarding the effect their decision had on the corporation's finances and by making their decision based not on the corporation's best interests, but rather on their personal view that baseball was a daytime sport. ${ }^{172}$ The defendants argued that the court should not interfere with the directors' honest business judgment unless the plaintiff shows fraud, illegality, or conflict of interest. ${ }^{173}$ Adopting

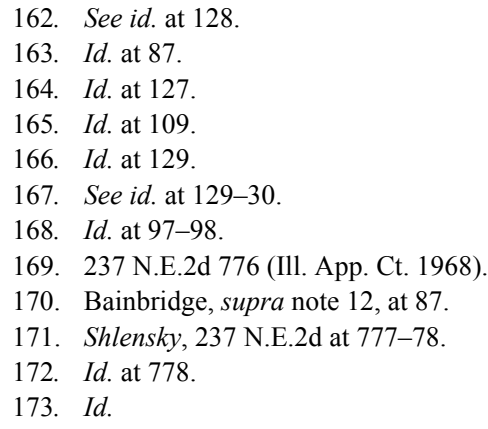


this approach, the court refrained from evaluating the directors' decision because it found that the decision was one properly before the directors and the motives alleged by the plaintiff evidenced no fraud, illegality, or conflict of interest in the decision. ${ }^{174}$ Professor Bainbridge also points to several other cases as examples of the abstention approach to the business judgment rule, ${ }^{175}$ including the recent Brehm v. Eisner, ${ }^{176}$ which he says "was not as pure an abstention decision as was Shlensky," but notes that "none of the preconditions set forth by [the Delaware Supreme Court in Brehm] contemplate substantive review of the merits of the board's decision." 177

2. The Flaws in an Abstention Approach to the Business Judgment Rule

Given limited liability and diversification, Professor Bainbridge believes shareholders would prefer judicial abstention to judicial review. ${ }^{178} \mathrm{He}$ argues that shareholders will tolerate risk-taking while directors will be opposed to risk-taking if they face legal liability on top of economic loss in the event a risky decision turns out badly. ${ }^{179}$ However, it is not clear that shareholders are willing to accept less accountability than they currently possess in shareholder derivative litigation. Post-Enron evidence suggests that shareholders are not. Shareholder proposals have achieved majority votes on initiatives such as eliminating staggered boards, separating the CEO position from the chairman of the board position, and limiting executive pay, all of which are designed to prevent directors and officers from becoming entrenched or promoting their own self-interests. ${ }^{180}$ Shareholder proposals also have attempted to eliminate poison pills, "which make companies more resistant to takeover bids." 181 In some instances, shareholder proposals have proven unnecessary because directors and management acceded to

174. Bainbridge, supra note 12, at 96-97 (citing Shlensky, 237 N.E.2d at 780).

175. Id. at 98 (citing Dodge v. Ford Motor Co., 170 N.W. 668, 684 (Mich. 1919) and Kamin v. Am. Express Co., 383 N.Y.S.2d 807, 810-11 (N.Y. Sup. Ct. 1976)).

176. 746 A.2d 244 (Del. 2000).

177. Bainbridge, supra note 12, at 100 (citing Brehm, 746 A.2d at $264 \&$ n.66).

178. See id. at $110-16$.

179. See id.

180. See Cynthia A. Williams \& John M. Conley, An Emerging Third Way? The Erosion of the Anglo-American Shareholder Value Construct, 38 CORNELL INT'L L.J. 493, 527-28 (2005) (discussing the 2003 proxy season).

181. Thomas Kostigen, Shareholder Activism Is Turning into Profits for Investors, THOMSON FinANCIAL NEWS, June 15, 2007. 
the shareholders' demands. ${ }^{182}$ Shareholders also are impacting corporate decision-making on such issues as environmental standards and labor rights. ${ }^{183}$

Even if Professor Bainbridge were correct in his assumptions that shareholders would prefer judicial abstention and that courts are not giving sufficient deference to directors' decisions under the current formulation of the business judgment rule, his proposed abstention approach does not offer the ideal solution. As described in Section a, the proposed abstention approach will not significantly alter shareholder derivative lawsuits, because it operates essentially the same in the context of litigation as the current formulation of the business judgment rule and otherwise is too limited to be useful as a replacement for the current formulation. In addition, Section $b$ explains that courts are unlikely to adopt the proposed abstention doctrine approach to the business judgment rule, because it does not fit within the abstention doctrines commonly recognized by courts and abstention otherwise does not present a desirable approach.

a. An Abstention Approach Operates the Same in Litigation as the Current Approach to the Business Judgment Rule

The proposed abstention approach to the business judgment rule does not function differently in practice than the current formulation of the business judgment rule. The current formulation views the business judgment rule as a presumption protecting directors' decisions, and that the presumption is rebuttable by plaintiffs in certain ways. Under the proposed abstention approach, courts begin with a presumption against review and "will abstain from reviewing the substantive merits of the directors' conduct unless the plaintiff can carry the very heavy burden of rebutting that presumption." 184 Thus, both the current approach and the

182. See Robert C. Illig, What Hedge Funds Can Teach Corporate America: A Roadmap for Achieving Institutional Investor Oversight, 57 AM. U. L. REV. 225, 260-61 (2007) (noting in 2006 that management at forty-five of forty-six companies that held a vote on shareholder proposals to eliminate staggered boards supported the change and that evidence showing that forty-four percent of shareholder proposals were withdrawn before the annual meeting suggested that many were mooted by management assent); see also Alistair Barr, Settlement Fever Grips Companies as Proxy Season Looms, THOMSON FinANCIAL NEWS, Mar. 4, 2006 (reporting in 2006 that more companies were settling with activist shareholders to avoid potentially damaging and embarrassing proxy contests at annual meetings).

183. Kostigen, supra note 181.

184. Bainbridge, supra note 12, at 87 (citing Shlensky v. Wrigley, 237 N.E.2d 776 (Ill. App. Ct. 1968)); see also id. at 90 (stating that the business judgment rule should establish "a presumption against judicial review of duty of care claims," such that a court "abstains from reviewing the substantive merits of the directors' conduct unless the plaintiff can rebut the business judgment 
proposed abstention approach establish a presumption of non-review, and courts will not review the challenged conduct unless the plaintiff can rebut that presumption.

In addition, the methods for rebutting the presumption of the business judgment rule are similar under both the proposed abstention approach and the current formulation. "[T]he abstention conception contemplates ... that, if the requisite preconditions are satisfied, there is no remaining scope for judicial review of the substantive merits of the board's decision." 185 Those preconditions include that the directors made a conscious decision, that the directors' conduct does not involve fraud or self-dealing, and that the directors acted in good faith with disinterested independence. ${ }^{186}$ Under current law, if the directors did not make a conscious decision to act or refrain from acting, then there is nothing to which the business judgment rule may apply because it applies only to scenarios involving a business judgment. ${ }^{187}$ Similarly, if plaintiff presents evidence of fraud or bad faith by the directors, then current law indicates that the business judgment rule presumption has been rebutted. ${ }^{188}$ Also, under the current formulation, plaintiffs may rebut the business judgment rule presumption by showing a breach of the duty of loyalty, ${ }^{189}$ which requires that directors be disinterested in making decisions for the corporation, or in other words refrain from self-

rule's presumption of good faith").

185. Id. at 99; see also id. at 129 (arguing courts should abstain from reviewing directors' decisions "except to verify that the relevant preconditions for review are not met"); id. at 87 (stating that courts should "refrain from reviewing board decisions unless exacting preconditions for review are satisfied").

186. Id. at 99 .

187. Aronson v. Lewis, 473 A.2d 805, 813 (Del. 1984), overruled on other grounds by Brehm v. Eisner, 746 A.2d 244 (Del. 2000) (noting the business judgment rule does not apply "where directors have either abdicated their functions, or absent a conscious decision, failed to act"); see also id. ("[A] conscious decision to refrain from acting may . . . be a valid exercise of business judgment and enjoy the protections of the rule."); Rabkin v. Philip A. Hunt Chem. Corp., 547 A.2d 963, 972 (Del. Ch. 1986) ("The business judgment rule may apply to a deliberate decision not to act . . .."); Kaplan v. Centex Corp., 284 A.2d 119, 124 (Del. Ch. 1971) ("Application of the rule of necessity depends upon a showing that informed directors did, in fact, make a business judgment authorizing the transaction under review.").

188. See In re The Walt Disney Co. Derivative Litig., 906 A.2d 27, 52 (Del. 2006) (stating that the business judgment rule presumption "can be rebutted if the plaintiff shows that the directors breached their fiduciary duty of care or loyalty or acted in bad faith"); see also Paglin v. Saztec Int'1 Inc., 834 F. Supp. 1184, 1200 (W.D. Mo. 1993) (noting "the business judgment rule does not apply when the act complained of is ultra vires, illegal or fraudulent"); Kamin v. Am. Express Co., 383 N.Y.S.2d 807, 810-11 (N.Y. Sup. Ct. 1976) (noting courts will not substitute their judgment for that of directors absent "fraud, dishonesty, or nonfeasance"); Shlensky v. Wrigley, 237 N.E.2d 776, 779 (Ill. App. Ct. 1968) ("The directors are chosen to pass upon [questions of policy and business management] and their judgment unless shown to be tainted with fraud is accepted as final."' (quoting Davis v. Louisville Gas \& Elec. Co., 142 A. 654, 659 (Del. Ch. 1928))).

189. See cases cited supra note 188. 
dealing, and that directors exercise independence in making those decisions. ${ }^{190}$ Moreover, both approaches limit courts to reviewing the decision-making process and not the merits of the decision. ${ }^{191}$ In sum, under both the current formulation and the proposed abstention approach, courts will refrain from reviewing board decisions unless similar conditions for review are satisfied. ${ }^{192}$

Furthermore, both approaches operate the same after the court determines whether the presumption of the business judgment rule has been rebutted. Under the current approach, if the plaintiff fails to rebut the presumption, then the business judgment rule protects the directors from liability and the case ends. ${ }^{193}$ Similarly, under the proposed abstention approach, if the court determines that the "exacting preconditions for review" have not been satisfied, then the court abstains from further review. ${ }^{194}$ On the other hand, if the plaintiff rebuts the presumption of the business judgment rule under either the current approach or the proposed abstention approach, the case proceeds. ${ }^{195}$

The abstention approach "leaves open the possibility of intervention in appropriate circumstances,"196 meaning when the exacting preconditions for review are satisfied. Professor Bainbridge, however, believes that judicial review is more likely to be the exception rather than

190. See Cede \& Co. v. Technicolor, Inc., 634 A.2d 345, 362 (Del. 1993) (stating a director must make decisions independently based on the merits of the transaction and must be disinterested in the outcome); see also Orman v. Cullman, 794 A.2d 5, 22 (Del. Ch. 2002) (stating the business judgment rule is rebutted where a majority of the directors either were "interested in the outcome of the transaction or lacked the independence to consider objectively whether the transaction was in the best interest of its company and all of its shareholders").

191. See Bainbridge, supra note 12 , at 128 (stating that under his abstention approach, "[t]he court begins with a presumption against review. It then reviews the facts to determine not the quality of the decision, but rather whether the decision-making process was tainted by self-dealing and the like."); see also Muir \& Schipani, supra note 102, at 726 (stating that courts focus on the "duty of care" analysis rather than on the "substantive decision," and that courts have been "reluctant to second-guess good faith business decisions").

192. Professor Bainbridge's listing of the preconditions for review does not include the duty of care. However, he specifically states that he would exempt duty of care cases involving structural issues from his proposed abstention doctrine. Bainbridge, supra note 12, at 129 . Professor Bainbridge also does not mention illegality or waste, so it is unclear how he would treat cases involving such allegations.

193. Citron v. Fairchild Camera \& Instrument Corp., 569 A.2d 53, 64 (Del. 1989).

194. Bainbridge, supra note 12 , at 87.

195. Presumably, at this point, the case continues the same under current law and under the proposed abstention approach because Professor Bainbridge does not state any different consequence than the current approach, which requires the directors to prove that the challenged transaction was fair to the corporation and its shareholders. In re The Walt Disney Co. Derivative Litig., 906 A.2d 27, 52 (Del. 2006); Emerald Partners v. Berlin, 787 A.2d 85, 90-91 (Del. 2001); Cede \& Co., 634 A.2d at 361; Aronson v. Lewis, 473 A.2d 805, 812 (Del. 1984), overruled on other grounds by Brehm v. Eisner, 746 A.2d 244 (Del. 2000).

196. Bainbridge, supra note 12 , at 127. 
the norm under his proposed abstention approach. ${ }^{197}$ The current formulation also establishes a presumption of non-review, but intervention is possible if the plaintiffs can meet their burden of rebutting that presumption. Perhaps the abstention approach raises the bar established by the presumption, but it seems to reflect only a difference in semantics. ${ }^{198}$ Indeed, Professor Bainbridge appears to recognize that the abstention approach does not provide any clearer framework for applying the business judgment rule:

The question is not whether the directors violated some bright-line precept, but whether their conduct satisfied some standard for judicial abstention. The greater flexibility inherent in standards frequently comes into play in business judgment rule jurisprudence as courts fine tune the doctrine's application to the facts at bar. Much of that fine tuning can be explained as an unconscious attempt to strike an appropriate balance between authority and accountability under specific factual circumstances. The principal law reform implication of this analysis thus may be that courts ought to be more explicit both about the fact that they are balancing competing concerns and about why they believe the balance struck in a particular case is the appropriate one.

The proposed abstention approach is simply not that different from the current approach, and therefore presents courts with no compelling reason to adopt it.

Finally, the proposed abstention doctrine appears too limited to be useful as a replacement for the current formulation of the business judgment rule. Because the abstention approach would not prohibit court review in cases alleging fraud or breaches of the duties of loyalty or good faith, ${ }^{200}$ it is designed to apply only to a small category of business judgment rule cases - those alleging a breach of the fiduciary duty of care. The abstention approach, however, is limited further to apply only to duty of care cases involving "operational issues, such as whether to install lighting in a baseball park" $" 201$ because "such decisions do not pose much of a conflict between the interests of directors and shareholders."202

197. Id. at $127-28$.

198. Cf. Sean J. Griffith, Good Faith Business Judgment: A Theory of Rhetoric in Corporate Law Jurisprudence, 55 DuKE L.J. 1, 1 (2005) (arguing that good faith functions as a rhetorical device rather than a substantive standard).

199. Bainbridge, supra note 12, at 128-29.

200. Professor Bainbridge does not include waste or illegality, but presumably the abstention approach would not prohibit court review of waste or illegality, which are typically treated the same as fraud by courts and scholars.

201. Bainbridge, supra note 12, at 129.

202. Id. 
The proposed abstention approach exempts any duty of care case that challenges a decision regarding structural issues, such as takeovers or mergers. ${ }^{203}$

In addition, a new approach limited to a portion of the duty of care cases appears unnecessary because directors rarely face legal liability for violations of the duty of care. ${ }^{204}$ Under the exculpatory statutes found in all fifty states, corporations possess the power to enact bylaw provisions limiting or eliminating director liability for breaches of the duty of care. $^{205}$ These statutes mean that directors will not be held financially liable for breaching their duty of care, and also that directors may obtain dismissal of lawsuits in which only monetary damages for an alleged duty of care violation are sought. ${ }^{206}$ Thus, the duty of care is relevant only for those cases seeking solely injunctive relief for an alleged duty of care breach and those corporations that have not adopted exculpatory provisions, although such corporations may carry insurance that will effectively eliminate directors' financial liability. ${ }^{207}$ Furthermore, the number of cases actually finding a violation of the duty of care is extremely small. $^{208}$

203. Id.

204. See Muir \& Schipani, supra note 102, at 726 (stating that courts focus on the "duty of care" analysis rather than on the substantive decision, and that courts have been reluctant to second guess good faith business decisions).

205. See Fairfax, supra note 135, at 412 (citing J. Robert Brown, Jr., The Irrelevance of State Corporate Law in the Governance of Public Companies, 38 U. RICH. L. REV. 317, 332 n.93 (2004)) (noting all fifty states had statutes enabling corporations to limit or eliminate personal liability for directors for breaches of the duty of care by 2003). See, e.g., DEL. CODE ANN. tit. 8, § 102(b)(7) (2008); Ga. Code ANN. § 14-2-202(b)(4) (West 2007); MinN. STAt. AnN. § 302A.251(4) (West 2008).

206. See Emerald Partners v. Berlin, 787 A.2d 85, 91 (Del. 2001) (“'A]doption of charter provision ... bars recovery of monetary damages from directors for a successful shareholder claim that is based exclusively upon establishing a violation of the duty of care."); Malpiede v. Townson, 780 A.2d 1075, 1095-96 (Del. 2001) ("[A] Section 102(b)(7) charter provision bars a claim that is found to state only a due care violation.").

207. Fairfax, supra note 135, at 414 (noting that "[t]he combination of indemnification provisions and [directors and officers'] insurance essentially eliminates directors' financial liability for breaching their fiduciary obligations").

208. See Stuart R. Cohn, Demise of the Director's Duty of Care: Judicial Avoidance of Standards and Sanctions Through the Business Judgment Rule, 62 TEX. L. REV. 591, 591 n.1-2 (1983) (noting only seven cases holding directors liable for all breaches of fiduciary duty other than self-interested transactions); see also In re The Walt Disney Co. Derivative Litig., 907 A.2d 693, 750 (Del. Ch. 2005) (“[D]uty of care violations are rarely found.”); Fairfax, supra note 135, at 40708 ("Over the last twenty years, a variety of mechanisms have contributed to a virtual elimination of legal liability for directors who breach their duty of care under state law."); Mark J. Loewenstein, The Quiet Transformation of Corporate Law, 57 SMU L. REV. 353, 369 (2004) ("Van Gorkom is famous, of course, because it marked one of the few times that a court found directors liable for breach of the duty of care."). 
The proposed abstention approach could potentially be different from the current formulation of the business judgment rule if it eliminated director liability for any breach of the duty of care. At times, Professor Bainbridge appears close to suggesting that courts abstain from reviewing all claims alleging that directors breached their duty of care and, in many ways, such a proposal would be the most defensible option. In the end, though, Professor Bainbridge does not advocate eliminating liability for all duty of care claims. ${ }^{209}$ Further, assuming courts are not providing sufficient deference to directors' decisions in business judgment rule cases, an approach focused solely on the duty of care is simply too limited to be useful.

\section{b. Courts Are Unlikely to Adopt an Abstention Approach to the Business Judgment Rule}

The proposed doctrine of abstention differs significantly from the abstention doctrines commonly applied by judges and litigators. Under the four primary abstention doctrines ${ }^{210}$ - known as Pullman, ${ }^{211}$ Burford, ${ }^{212}$ Younger, ${ }^{213}$ and Colorado River ${ }^{214}$ abstention, after the major

209. Professor Bainbridge's proposal may exempt duty of care cases involving structural issues due to a concern about potential conflicts of interest between the board and the shareholders in final period decisions, such as mergers and sales. To that extent, such an exemption is unnecessary because such concerns already are encompassed within the duty of loyalty and thus exempt under his proposed abstention doctrine.

210. Charles Alan Wright \& Mary Kay Kane, LAw of Federal Courts $§ 52$, at 325 (6th ed. 2002) ("These various doctrines overlap at times, and the courts have not always distinguished them clearly.").

211. The Pullman abstention doctrine allows a federal court "to avoid decision of a federal constitutional question when the case may be disposed of on questions of state law." Id.; R.R. Comm'n of Tex. v. Pullman Co., 312 U.S. 496, 501-02 (1941); see also WRIGHT \& KANE, supra note $210, \S 52$, at 326 (stating that "the state court decides the state issues, and the federal court avoids deciding a federal constitutional question prematurely or unnecessarily, since if the state court should hold the order unauthorized as a matter of state law, there will be no need for the federal court to pass on the federal [constitutional] question"). The state law must be "fairly subject to an interpretation which will render unnecessary or substantially modify the federal constitutional question." Babbitt v. United Farm Workers Nat'l Union, 442 U.S. 289, 306 (1979) (quoting Harman v. Forssenius, 380 U.S. 528, 534-35 (1965)); WRIGHT \& KANE, supra note 210, § 52, at 326 (noting also that Pullman abstention "will not be ordered if the state law is clear on its face, or if its meaning has already been authoritatively decided by the state courts, or if the constitutional issue would not be avoided or changed no matter how the [state law] is construed").

212. The Burford abstention doctrine allows a court to dismiss a case in order to avoid needless conflict with a state's administration of its own affairs. WRIGHT \& KANE, supra note 210, § 52, at 325, 330; Burford v. Sun Oil Co., 319 U.S. 315, 317-18 (1943); see also New Orleans Pub. Serv., Inc. v. Council of New Orleans, 491 U.S. 350, 361 (1989) ("Where timely and adequate state-court review is available, a federal court sitting in equity must decline to interfere with the proceedings or orders of state administrative agencies: (1) when there are 'difficult questions of state law bearing on policy problems of substantial public import whose importance transcends the result in the case then at bar'; or (2) where the 'exercise of federal review of the question in a case and in similar cases 
Supreme Court cases recognizing them-federal courts may dismiss or stay actions pending before them in certain circumstances even though the courts have jurisdiction under the Constitution and federal statute. ${ }^{215}$ All of these abstention doctrines represent a sorting of the relationship between state and federal courts, and "reflect a complex of considerations designed to soften the tensions inherent in a system that contemplates parallel judicial processes." 216 Thus the purpose of these abstention doctrines "is to preserve the balance between state and federal sovereignty." ${ }^{217}$ The proposed doctrine of abstention for the business judgment rule does not fit that overarching rationale. ${ }^{218}$ Applying an abstention approach to the business judgment rule does not soften the tensions in the relationship between state and federal courts, or the

would be disruptive of state efforts to establish a coherent policy with respect to a matter of substantial public concern."”).

213. The Younger abstention doctrine requires federal courts to "refrain from hearing constitutional challenges to state action under circumstances in which federal action is regarded as an improper intrusion on the right of a state to enforce its laws in its courts." WRIGHT \& KANE, supra note 210, § 52A, at 341-42; Younger v. Harris, 401 U.S. 37, 43-46 (1971) (holding that a federal court should not enjoin a prior state criminal prosecution except when necessary to prevent immediate irreparable injury). The Younger abstention doctrine has since been expanded to quasicriminal cases, quasi-judicial proceedings, and to civil proceedings. William A. Calhoun, II, Comment, Arthur Miller's Death of a Doctrine or Will the Federal Courts Abstain from Abstaining? The Complex Litigation Recommendations' Impact on the Abstention Doctrines, 1995 BYU L. REV. 961, 974 (1995); Mathew D. Staver, The Abstention Doctrines: Balancing Comity with Federal Court Intervention, 28 SETON HALL L. REV. 1102, 1121-25 (1998).

214. The Colorado River abstention doctrine avoids duplicate litigation by allowing a federal court to stay or dismiss an action on the ground that a similar action is "pending in state court in which the controversy between the parties can be resolved." WRIGHT \& KANE, supra note 210, § 52, at 325, 338; Colo. River Water Conservation Dist. v. United States, 424 U.S. 800, 818 (1976). Although the pendency of a state court action does not prohibit an action regarding the same matter in federal court, dismissal in such circumstances may be permissible in some exceptional cases. Colo. River, 424 U.S. at 818 (listing four factors as relevant in deciding whether exceptional circumstances exist: (1) assumption by the state court of jurisdiction over any property, (2) any contention that the federal forum is less convenient to the parties than the state forum, (3) avoidance of piecemeal litigation, and (4) the order in which jurisdiction was obtained by the concurrent forums); see also Moses H. Cone Mem'l Hosp. v. Mercury Constr. Corp., 460 U.S. 1, 26 (1983) (adding two additional factors: (1) whether federal law provides the rule of decision on the merits because "the presence of federal-law issues must always be a major consideration weighing against surrender" and (2) "the probable inadequacy of the state-court proceedings to protect [the litigant's] rights").

215. WRIGHT \& KANE, supra note $210, \S 52$, at 325.

216. Pennzoil Co. v. Texaco, Inc., 481 U.S. 1, 11 n.9 (1987).

217. Staver, supra note 213, at 1153; WRIGHT \& KANE, supra note 210, § 52, at 327 (stating that Pullman abstention is necessary to satisfy the principles of federalism); Calhoun, supra note 213, at 971-74 (noting that federalism concerns constituted the Supreme Court's rationale for the Burford and Younger abstention doctrines).

218. In addition, these recognized state/federal abstention doctrines are criticized on numerous grounds, including that they impose unnecessary cost, delay and uncertainty, and also that they represent judicial usurpation of legislative authority. See Leonard Birdsong, Comity and Our Federalism in the Twenty-First Century: The Abstention Doctrines Will Always Be with Us-Get Over It!!, 36 CREIGHTON L. REV. 375, 383-87 (2003). 
relationship between separate sovereigns. ${ }^{219}$ Rather, the tension in such cases is in the purely private relationship between directors and shareholders. For this reason, courts are unlikely to adopt an abstention doctrine approach to the business judgment rule.

A lesser known and lesser cited abstention doctrine, however, is potentially analogous to the proposed abstention approach to the business judgment rule: the ecclesiastical abstention doctrine. ${ }^{220}$ The ecclesiastical abstention doctrine states that courts must not review an issue that is "strictly and purely ecclesiastical in its character ... which concerns theological controversy, church discipline, ecclesiastical government, or the conformity of the members of the church to the standard of morals required of them ...."221 The rationale behind this

219. Using the rationale of the Colorado River abstention doctrine, some courts have recognized an international abstention doctrine, which may apply when parallel cases are pending in domestic and international courts. See, e.g., Turner Entm't Co. v. Degeto Film GmbH, 25 F.3d 1512, 1518 (11th Cir. 1994); Andrés Rivero et al., A Comity of Errors: Understanding the International Abstention Doctrine, 17 FLA. J. INT'L L. 405, 409 (2005) (discussing the Second Circuit's recognition of an international abstention doctrine). The Supreme Court also has recognized a tribal abstention doctrine, also known as the tribal exhaustion doctrine, which requires a federal court to abstain from exercising its concurrent jurisdiction until tribal court remedies have been exhausted. Iowa Mut. Ins. Co. v. LaPlante, 480 U.S. 9, 16, n.8 (1987) (stating that for reasons "analogous to principles of abstention," a federal district court must "stay its hand in order to give the tribal court a "full opportunity to determine its own jurisdiction."' (quoting Nat'l Farmers Union Ins. Cos. v. Crow Tribe of Indians, 471 U.S. 845, 857 (1985))); see also Blake A. Watson, The Curious Case of Disappearing Federal Jurisdiction over Federal Enforcement of Federal Law: A Vehicle for Reassessment of the Tribal Exhaustion/Abstention Doctrine, 80 MARQ. L. REV. 531 (1996).

220. Scholars also have gleaned a similar academic abstention doctrine, which states that courts should not interfere in the relationship between a school and its students or faculty when the dispute is academic in nature. See, e.g., David L. Dagley \& Carole A. Veir, Subverting the Academic Abstention Doctrine in Teacher Evaluation: How School Reform Legislation Defeats Itself, 2002 BYU EDUC. \& L.J. 123, 124 (2002) ("[A] court will abstain from interfering with decisions of school officials and school boards unless the decision represents an abuse of discretion, is irrational, or violates constitutional or statutory rights."); Steven G. Olswang, Academic Abstention Stronger than Ever, Despite Vaksman, 26 J.L. \& EDUC. 91 (1997). The Supreme Court has articulated the view that universities can best perform their missions when they are free from governmental or judicial interference. See, e.g., Regents of Univ. of Mich. v. Ewing, 474 U.S. 214, 225 (1985) ("When judges are asked to review the substance of a genuinely academic decision ... they should show great respect for the faculty's professional judgment. Plainly, they may not override it unless it is such a substantial departure from accepted academic norms as to demonstrate that the person or committee responsible did not actually exercise professional judgment."). Board of Curators of Univ. of Mo. v. Horowitz, 435 U.S. 78, 90 (1978) ("Like the decision of an individual professor as to the proper grade for a student in his course, the determination of whether to dismiss a student for academic reasons requires an expert evaluation of cumulative information and is not readily adapted to the procedural tools of judicial or administrative decisionmaking."). It applies to decisions on such matters as student admissions, grading, dismissals, faculty hiring, and award of tenure. Terrence Leas, Higher Education, the Courts, and the "Doctrine" of Academic Abstention, 20 J.L. \& EDUC. 135 (1991).

221. Watson v. Jones, 80 U.S. 679, 733-34 (1871) (holding that a state court was bound by an ecclesiastic tribunal's decision regarding whether anti-slavery or pro-slavery supporters in a local Presbyterian church were entitled to control the church property); see also Serbian E. Orthodox 
form of abstention is that a church is a voluntary organization and the members that join the church consent to the church's authority to make determinations about their status as members. ${ }^{222}$ For the members' consent to be meaningful and for them to have assurance that those with competence in ecclesiastical matters will resolve ecclesiastical disputes, courts must abstain from interfering in such matters. ${ }^{223}$

However, the Supreme Court has not issued a blanket abstention doctrine for ecclesiastical matters. The Supreme Court has stated that ecclesiastical tribunals may function independently in determining disputes within their proper sphere of governance, but when such tribunals violate personal or property rights, their determinations are subject to judicial review. ${ }^{224}$ It also has given courts permission to conduct a limited review of ecclesiastical decisions for fraud, collusion, or arbitrariness. ${ }^{225}$

Thus, under the ecclesiastic abstention doctrine, the Supreme Court has decided that courts should not interfere in the relationship between the church and its members when the dispute is ecclesiastical in nature. Analogously, one could argue that courts should not interfere in the relationship between a corporation's board of directors and its

Diocese for U.S. \& Can. v. Milivojevich, 426 U.S. 696, 709 (1976) ("For where resolution of the disputes cannot be made without extensive inquiry by civil courts into religious law and polity, the First and Fourteenth Amendments mandate that civil courts shall not disturb the decisions of the highest ecclesiastical tribunal within a church of hierarchical polity, but must accept such decisions as binding on them, in their application to the religious issues of doctrine or polity before them.").

222. Cf. Watson, 80 U.S. at 728-29 ("All who unite themselves to such a body do so with an implied consent to this government, and are bound to submit to it.").

223. Id.; John S. Brennan, The First Amendment Is Not the 8th Sacrament: Exorcizing the Ecclesiastical Abstention Doctrine Defense from Legal and Equitable Claims for Sexual Abuse Based on Negligent Supervision or Hiring of Clergy, 5 T.M. COOLEY J. PRAC. \& CliniCAL L. 243, 260 (2002) (stating that where "the ecclesiastical decision involves an internal dispute between parties that have voluntarily subjected themselves to church authority, where the dispute involves a question of discipline, faith, ecclesiastical rule, custom, or law, and where the decision does not result in a violation of morality, property or infringe on personal rights, civil courts must accept them as binding in their application to the case before them")

224. See Watson, 80 U.S. at 728 ("In this country the full and free right to entertain any religious belief, to practice any religious principle, and to teach any religious doctrine which does not violate the laws of morality and property, and which does not infringe personal rights, is conceded to all."); $i d$. at 732-33 (stating that courts would not be bound by an ecclesiastical tribunal's decision that a man is guilty of murder nor by an ecclesiastical tribunal's resolution of property rights between church members when the dispute does not depend on a religious question).

225. Gonzalez v. Roman Catholic Archbishop of Manila, 280 U.S. 1, 16 (1929) ("In the absence of fraud, collusion, or arbitrariness, the decisions of the proper church tribunals on matters purely ecclesiastical, although affecting civil rights, are accepted in litigation before the secular courts as conclusive, because the parties in interest made them so by contract or otherwise."); see also Milivojevich, 426 U.S. at 712 (stating that "although Watson had left civil courts no role to play in reviewing ecclesiastical decisions... Gonzalez first adverted to the possibility of 'marginal civil court review" when such decisions are challenged as products of "fraud, collusion, or arbitrariness"” (quoting Presbyterian Church v. Hull Church, 393 U.S. 440, 447 (1969))). 
shareholders when the dispute is business in nature. However, in reality it is not so simple to determine the disputes from which courts should abstain, and courts have not applied the ecclesiastical abstention doctrine consistently or easily. ${ }^{226}$ Thus, the question of when courts should abstain from resolving disputes between directors and shareholders will prove no easier to answer in the corporate context than when it is in the ecclesiastical arena. Indeed, the same problem exists in applying the current business judgment rule formulation to real-world disputes between shareholders and directors.

In addition, for all of these recognized abstention doctrines, the Supreme Court has made it clear that abstention is the "extraordinary" exception and not the rule. ${ }^{227}$ Professor Bainbridge's proposed abstention doctrine reverses that principal. Under his proposed abstention doctrine approach to the business judgment rule, abstention would be the rule and judicial review would be the extraordinary exception. ${ }^{228}$ Moreover, under the proposed abstention approach, the court must review the decision to see if the plaintiff has met the preconditions for review, which seems to suggest more judicial review than occurs in these recognized abstention doctrines. For all these reasons, courts are unlikely to adopt an abstention approach to the business judgment rule and the Delaware Supreme Court has arguably rejected Professor Bainbridge's abstention approach by reaffirming the

226. Brennan, supra note 223, at 268 ("Yet courts faced with such disputes have not acted consistently in applying the doctrine. To some extent, this is because not enough focus has been placed on the doctrine's limitations: First, the doctrine should apply only when the litigants are members of the church who have consented to being governed and bound by church authority on the issue in question. Second, the doctrine applies to matters that are ecclesiastical in character such as theological controversy, church discipline, ecclesiastical government, or the conformity of the members of the church to a moral standard. If ecclesiastical conduct can be reviewed without the need to review such issues, the court may determine its legal effect in the context of the dispute before it. Third, the ecclesiastical decision cannot violate the laws of morality and property or infringe on personal rights.").

227. Colo. River Water Conservation Dist. v. United States, 424 U.S. 800, 813 (1976) ("Abstention from the exercise of federal jurisdiction is the exception, not the rule. 'The doctrine of abstention, under which a District Court may decline to exercise or postpone the exercise of its jurisdiction, is an extraordinary and narrow exception to the duty of a District Court to adjudicate a controversy properly before it. Abdication of the obligation to decide cases can be justified under this doctrine only in the exceptional circumstances where the order to the parties to repair to the state court would clearly serve an important countervailing interest." (quoting County of Allegheny v. Frank Mashuda Co., 360 U.S. 185, 188-89 (1959))). The Supreme Court continues to cite this same language from Colorado River in more recent opinions. See, e.g., Quackenbush v. Allstate Ins. Co., 517 U.S. 706, 728 (1996); Moses H. Cone Mem’l Hosp. v. Mercury Constr. Corp., 460 U.S. 1, 14 (1983).

228. Bainbridge, supra note 12, at 127-28 ("If the business judgment rule is framed as an abstention doctrine, however, judicial review is more likely to be the exception rather than the rule."). 
current formulation of the business judgment rule. ${ }^{229}$ Indeed, Professor Bainbridge complained as much on his website after the Delaware Supreme Court issued its Disney opinion. ${ }^{230}$

Professor Bainbridge's proposed doctrine of abstention may simply be suggesting that courts give more "deference" to directors, as opposed to attempting to draw an analogy to "abstention" as that term is understood by litigators and judges. Alternatively, Professor Bainbridge's proposal could be read as suggesting courts should possess less discretion when ruling on assertions of the business judgment defense. Either way, as explained in the preceding section, the proposed abstention approach does not present an effective alternative to the current business judgment rule formulation.

\section{A BETTER APPROACH FOR BALANCING AUTHORITY AND ACCOUNTABILITY THROUGH THE BUSINESS JUDGMENT RULE}

None of the existing proposals for the business judgment rule, as outlined in Part III, have settled the debate as to the proper balancing of authority and accountability in shareholder derivative litigation. So the question remains: is there a better approach for balancing authority and accountability in shareholder derivative litigation? As shown in Part II, the balancing of authority and accountability occurs throughout the law, and the appropriate balance point can differ depending on a variety of factors such as the complexity of the area of law and policy considerations. Such balancing can occur through procedural or substantive mechanisms, or some combination of both, in the context of litigation.

Regardless of one's viewpoint as to the proper balancing of authority and accountability in the corporate context, a potential for abuse arises from the procedures surrounding the courts' current application of the business judgment rule. Indeed, those procedures may contribute to the critics' perception that courts are not providing sufficient deference to directors' decisions. Currently, defendants may assert the business judgment defense in pretrial dispositive motions, such as motions to

229. In re The Walt Disney Co. Derivative Litig., 906 A.2d 27, 52, $73-75$ (Del. 2006).

230. Stephen M. Bainbridge, Disney: Jacobs on the BJR, Business Associations Blog (June 8, 2006), http://www.businessassociationsblog.com/lawandbusiness/comments/disney_jacobs_on_the bjr (last visited Oct. 5, 2008) (quoting the Disney opinion's explanation of the current business judgment rule formulation and stating: "Sigh. I inveighed against precisely this formulation in my article The Business Judgment Rule as Abstention Doctrine. It's very disappointing to see such a perceptive and thoughtful jurist as [Delaware Supreme Court Justice] Jacobs perpetuate this misconception.”). 
dismiss or motions for summary judgment, and at trial, ${ }^{231}$ but courts are not required to render a final decision as to the applicability of the business judgment rule until trial. Only when the court grants a pretrial dispositive motion asserting the business judgment defense, does it render a final judgment on the issue. ${ }^{232}$ For example, if the court rules that the business judgment rule applies at the motion to dismiss stage, the court abstains from further review and the case ends without any discovery being taken and without a trial

On the other hand, when a court denies motions to dismiss or motions for summary judgment asserting the business judgment rule defense, it is not a final resolution of the applicability of that defense as it can be reasserted and reevaluated at any point up to and including trial. ${ }^{233}$ This process destroys at least some of the business judgment rule's value, because it likely allows discovery and perhaps a trial in which the court may ultimately rule that the directors' decision is protected by the business judgment defense. ${ }^{234}$ Directors are not receiving the intended benefit of the business judgment defense when they are forced to go through discovery and trial before the court makes its final decision that the directors are entitled to the protection of the business judgment defense. Similarly, the non-plaintiff shareholders and the corporation suffer to the extent that corporate resources were devoted to such fruitless litigation. Importantly, this procedural problem pertains to all types of business judgment rule cases, not just the duty of care cases that scholars frequently criticize.

Section A analyzes the benefits of a procedural mechanism versus a substantive mechanism for balancing authority and accountability in the corporate context. Having recognized the potential advantages of a procedural mechanism, Section B then explains that the qualified immunity doctrine offers a procedural approach for the business judgment rule that better balances authority and accountability in shareholder derivative litigation.

231. See cases cited supra note 111.

232. See generally 28 U.S.C. § 1291; Liberty Mut. Ins. Co. v. Wetzel, 424 U.S. 737, 744-46 (1976) (concluding that only final decisions of a district court are appealable, except under 28 U.S.C. $\S 1292)$.

233. In re The Walt Disney Co. Derivative Litig., 907 A.2d 693, 697, 754, 757-59 (Del. Ch. 2005) (holding defendants were entitled to business judgment rule protection after a lengthy trial, after having denied motions to dismiss and a motion for summary judgment asserting the business judgment rule defense).

234. See Scarlett, supra note 3, 603-06. 


\section{A. Procedural Versus Substantive Mechanisms for Balancing Authority and Accountability in Shareholder Derivative Litigation}

Assuming that shareholders should continue to possess the right to hold directors accountable for their decisions through shareholder derivative litigation, at least in certain circumstances, then the question is how should courts apply the business judgment rule to balance authority and accountability in such cases. Although the business judgment defense could be abolished, such a radical proposal has not been adopted by any court or legislative body. Thus, this Article assumes that the business judgment rule will continue to be the mechanism that balances authority and accountability in shareholder derivative litigation, and proposes a new approach to the business judgment defense that could be adopted either through courts' further development of common law or through statutory enactments.

Applying the business judgment rule in litigation will never be an entirely objective endeavor. Although called a rule, the business judgment rule is universally recognized as a standard. ${ }^{235}$ That standard must be applied to the facts of a pending case, and thus applying the business judgment rule will always involve a subjective component. Recognizing that the business judgment defense is a standard, not a rule, a new approach to the business judgment defense requires the development of a standard that will guide courts in deciding whether the business judgment defense should apply in a particular case. A standard, alone, will not eliminate potential errors in the subjective application of those standards. However, as noted in Part II, a standard combined with transparency, such as that provided by reasoned court opinions, may provide enhanced consistency and predictability in the application of the business judgment defense, which is necessary for that formulation to function properly over time. Combining these two aspects, standards and transparency, fit two common accountability mechanisms:

(1) enhanced structure for decision-makers, which limits their authority and discretion ex ante through guidelines and standards, yielding more consistent decision-making across cases, and (2) transparency with respect to the actions of decision-makers and the outcomes of their

\footnotetext{
235. Bainbridge, supra note 12, at 128 ("[T]he business judgment rule clearly is misnamed; it is a standard, not a rule."); Branson, supra note 101, at 631 (noting the business judgment rule "has no mandatory content," "involves no substantive 'do's' or 'don'ts' for corporate directors or officers," and "entail[s] only slight review of business decisions").
} 
decisions, thereby permitting ex post monitoring in light of the established guidelines, which, in turn, serve as criteria for evaluation. ${ }^{236}$

Thus, that standard will provide directors with guidance on how to conduct their activities so as to obtain the protections of the business judgment rule. It also will help shareholders and their attorneys predict the likely outcome of potential litigation, which may allow shareholders to maintain a method of accountability over boards of directors while preventing frivolous shareholder litigation. Transparency will also enable higher courts, legislatures, and the public to monitor trial courts' application and enforcement of the standard.

The business judgment standard could be implemented as a procedural or a substantive mechanism. At times, the business judgment rule has been seen as substantive and other times procedural. ${ }^{237}$ Although in theory it does not matter whether the business judgment defense is expressed as a procedural mechanism or a substantive mechanism, it does make a practical difference in litigation. It determines when the decision is made as to whether the business judgment rule applies to protect the directors from liability. It also potentially alters who makes the decision as to whether the business judgment rule applies. In addition, it affects the complexity of the standard that may guide the decision maker in determining if the business judgment rule applies. It may even affect the frequency with which the business judgment rule is deemed to protect directors' decisions.

If the business judgment rule is seen as a procedural mechanism for balancing authority and accountability, the judge would decide whether the business judgment rule applies and likely could do so on a pretrial dispositive motion. Thus, the decision could occur early in the litigation before discovery occurs. ${ }^{238}$ If a preliminary decision could be made by a court to assess the likelihood of the shareholders' success on the merits - overcoming the business judgment defense - then significant amounts of time and money could be saved to the benefit of the corporation, the directors, and all the shareholders. Further, the decision

236. Rabinovich-Einy, supra note 22 , at 260.

237. Compare Brehm v. Eisner, 746 A.2d 244, 264 (Del. 2000); Kamin v. Am. Express Co., 383 N.Y.S.2d 807, 810-11 (N.Y. Sup. Ct. 1976), aff'd, 387 N.Y.S.2d 993 (N.Y. App. Div. 1976); Shlensky v. Wrigley, 237 N.E.2d 776, 780 (Ill. App. Ct. 1968); Dodge v. Ford Motor Co., 170 N.W. 668, 684 (Mich. 1919), with In re The Walt Disney Co. Derivative Litig., 906 A.2d 27, 52 (Del 2006); and Cede \& Co. v. Technicolor, Inc., 634 A.2d 345, 361 (Del. 1993), decision modified, 636 A.2d 956 (Del. 1994).

238. Stoner v. Walsh, 772 F. Supp. 790, 800 (S.D.N.Y. 1991) (stating mere allegations of director impropriety do not entitle a plaintiff to discovery). 
could be based on a defined standard with little judicial discretion, and thus presumably without a searching review of the board's decision. For instance, if the court determined that the board made a decision, acted within its authority, and acted without any conflict of interest, then the court could defer to the board's authority and review the board's decision no further. With a procedural mechanism, one would predict that the balance would tip in favor of authority.

If the business judgment rule is seen as a substantive mechanism for balancing authority and accountability, then one would predict that the balance would tip more toward accountability as the decision maker must evaluate the substance of the decision. With a substantive standard, the decision could be made by a judge or a jury. Whoever the decision maker, the decision would occur later in litigation and likely after discovery because a substantive standard requires the weighing of facts as developed through discovery. Inevitably, it is a more discretionary standard, allowing a more searching review of the board's decision. If the decision is made after discovery, more intrusion into the board's decision-making process will occur and likely more disruption of the board's operations will be experienced. Also, it will be more expensive for directors, the corporation, and ultimately all the shareholders. Further, a substantive mechanism yields a fact-based decision, which makes appellate review more complicated and also makes it more difficult for the public and legislatures to monitor its application and enforcement. In addition, it is more challenging for directors to regulate their conduct ex ante to avoid litigation with a substantive standard.

For these reasons, implementing the business judgment rule by procedural mechanism appears to be the better choice. As seen in Part II.B.2., the PLRA uses procedural rules to prohibit prison administrators' authority from being disturbed by frequent litigation and to effectively limit such litigation to truly egregious cases. First, the PLRA requires plaintiffs to exhaust all administrative remedies before initiating a lawsuit. Second, it requires courts to dismiss claims that are frivolous, malicious, or fail to state a claim upon which relief can be granted. Third, it imposes heightened pleading standards. Finally, it limits the relief that judges may order, establishes the findings upon which relief must be based, and sets the length of such relief. Some of the PLRA procedures could be adapted to the business judgment defense, such as heightened pleading requirements and the limitations on remedies. ${ }^{239}$ In

239. This author elsewhere has advocated for heightened pleading standards for shareholder derivative actions. Scarlett, supra note 3, at 637-38. 
fact, the PLRA's exhaustion of administrative remedies requirement is already present in the demand requirement in shareholder derivative litigation. ${ }^{240}$

The PLRA, however, does not present an ideal analogy for shareholder derivative litigation because the authority versus accountability dilemma in prisoner litigation is quite different from shareholder litigation. As explained in Part II.B.2., prison administrators hold absolute authority over prisoners and litigation is the only means by which prisoners can attempt to hold prison administrators accountable. By contrast, directors do not possess absolute authority in the corporate context and litigation is not a shareholder's sole method of accountability. For this reason, the qualified immunity defense, which utilizes procedures similar to the PLRA, may present a more useful analogy for shareholder derivative litigation.

\section{B. The Qualified Immunity Defense}

The qualified immunity defense shields government officials from liability for civil damages in certain circumstances. The original formulation of the qualified immunity defense "depended on both objective and subjective factors: what the official reasonably knew at the time of his action; whether the official had a good faith belief that he was acting in accordance with constitutional requirements; and whether the official intended to do 'other injury' to the [plaintiff]." ${ }^{\text {241 }}$ This formulation sought to balance the interests of government officials and the potential public victims of their conduct. ${ }^{242}$ But the substantive portion of the qualified immunity defense often required resolution of factual disputes surrounding the defendant's intent in taking the allegedly unconstitutional action. ${ }^{243}$ Similarly, when the parties contested what actions the defendant took, then discovery was necessary to resolve the

240. In most states and in federal court, a shareholder must make a demand on the board of directors before filing a shareholder derivative action on behalf of the corporation. See, e.g., DEL. СH. CT. R. 23.1; FED. R. CIV. P. 23.1. Thus, the board may be given an opportunity to rectify a challenged decision before litigation is commenced, but the demand requirement will be excused if futile and a board's wrongful rejection of a demand will not prohibit shareholder derivative litigation. See Scarlett, supra note 3, at 596-97.

241. Diana Hassel, Living a Lie: The Cost of Qualified Immunity, 64 Mo. L. REv. 123, 129 (1999); see also Alan K. Chen, The Facts About Qualified Immunity, 55 EMORY L.J. 229, 237 (2006) (noting that the original formulation of the qualified immunity defense "included both a subjective and objective component").

242. Hassel, supra note 241, at 129.

243. Id. at 130; see also Engle v. Townsley, 49 F.3d 1321, 1323 (8th Cir. 1995) (describing the issues of material fact that may prevent summary judgment on a qualified immunity defense). 
qualified immunity issue. ${ }^{244}$ Thus, it was almost impossible for defendants to get dismissal on the qualified immunity defense before trial. ${ }^{245}$ "This delay in the resolution of the lawsuit was perceived to be unfair to defendants as it embroiled them in potentially meritless and lengthy litigation." 246

The Supreme Court eventually reformulated the qualified immunity defense consistent with its original purposes "to protect government officials who acted reasonably from frivolous lawsuits" and "to provide damages for plaintiffs when a government official's conduct was particularly blameworthy." 247 In doing so, the Supreme Court moved from a primarily substantive test to a more objective test using procedural mechanisms to preserve the value of the qualified immunity defense. The Supreme Court was apparently concerned that under the prior formulation, government officials would be punished unfairly when conducting their duties in good faith and might not vigorously fulfill their duties for fear of liability. ${ }^{248}$ Thus, in Harlow v. Fitzgerald, ${ }^{249}$ the Supreme Court eliminated the subjective requirement of good faith from the qualified immunity defense and articulated a new formulation of the defense. Pursuant to this new formulation, the Supreme Court held "that government officials performing discretionary functions generally are shielded from liability for civil damages insofar as their conduct does not violate clearly established statutory or constitutional rights of which a reasonable person would have known."250 This new formulation "appears to balance competing interests; to punish only the truly guilty, not just the hapless; to provide a remedy to the worthy plaintiff; to protect the judicial system from being logjammed with frivolous claims;

\footnotetext{
244. See DiMeglio v. Haines, 45 F.3d 790, 795 (4th Cir. 1995).

245. Chen, supra note 241 , at 238 ("The Court claimed that the subjective component made it relatively easy for plaintiffs to defeat qualified immunity claims simply by alleging that the defendant acted maliciously or with an otherwise improper motive. It speculated that the experience of lower courts in applying the subject good faith part of the qualified immunity test demonstrated that this test was incompatible with the desire for early termination because disputes about officials' good faith were often not capable of resolution without a trial. In other words, such claims were likely to require resolution of material fact disputes.") (internal footnotes omitted).

246. Hassel, supra note 241, at 130.

247. Id. at 126 .

248. Chen, supra note 241 at 236.

249. 457 U.S. 800 (1982).

250. Id. at 818; see also Barbara E. Armacost, Qualified Immunity: Ignorance Excused, 51 VAND. L. REV. 583, 583 (1998) ("Public officials receive qualified immunity from damages liability for constitutional violations if they reasonably could have believed their actions were constitutional under clearly established law."); Hassel, supra note 241, at 130-31.
} 
and to promote good government." 251 Thus, these new procedures would permit " "unsubstantial lawsuits [to] be quickly terminated." 252

Because the new formulation of the qualified immunity defense is objective, the Supreme Court stated that it could be determined at the beginning of the lawsuit before extensive discovery occurs. ${ }^{253}$ On summary judgment, before any discovery has occurred, the current formulation of the qualified immunity defense requires "trial courts to grant immunity where the law was unclear or, even if the law was clear, where a reasonable officer might have mistaken it."254

On summary judgment, the judge appropriately may determine, not only the currently applicable law, but whether that law was clearly established at the time an action occurred. If the law at that time was not clearly established, an official could not reasonably be expected to anticipate subsequent legal developments, nor could he fairly be said to "know" that the law forbade conduct not previously identified as unlawful. Until this threshold immunity question is resolved, discovery should not be allowed.

In other words, qualified immunity is appropriate "where the general legal principal had not been established, where the law changed, where the legal standard had been stated only in broad and amorphous terms, or where the conduct at issue was not clearly proscribed."256 Thus, after Harlow, this new qualified immunity formulation provided not only immunity from liability, but also immunity from standing trial. ${ }^{257}$ In addition, to guarantee that defendants entitled to qualified immunity were not trapped in litigation, the Supreme Court subsequently held that pretrial orders denying qualified immunity were entitled to immediate appeal. $^{258}$

The Supreme Court's procedural framework for evaluating the qualified immunity defense has undoubtedly shifted the balance more toward authority, and at the expense of accountability according to some

251. Hassel, supra note 241, at 133.

252. Harlow, 457 U.S. at 808 (quoting Butz v. Economou, 438 U.S. 478, 507-08 (1978)).

253. Chen, supra note 241, at 238.

254. Jonathan M. Freiman, The Problem of Qualified Immunity: How Conflating Microeconomics and Law Subverts the Constitution, 34 IDAHO L. REV. 61, 67 (1997).

255. Harlow, 457 U.S. at 818.

256. David Rudovsky, How to Handle Unreasonable Force Litigation: Prosecution and Defense Strategies in Police Misconduct Cases, 590 PRACTISING L. InSt./Lit. 259, 274 (1998).

257. Hassel, supra note 241, at 131.

258. Mitchell v. Forsyth, 472 U.S. 511, 524-25 (1985); Chen, supra note 241, at 239-41 (discussing Mitchell v. Forsyth). 
scholars. ${ }^{259}$ The frequently stated objectives for implementing this new framework were to allow early resolution of such claims, to enforce defendants' right not to stand trial, and arguably to reduce the number of such claims. In these respects, the qualified immunity defense can be seen as similar to the business judgment defense. Both defenses are intended to protect defendants from liability except in cases of misconduct. To the extent that the normative judgment is made that the business judgment defense must be weighted more toward authority or is intended to grant directors immunity from trial when it applies, then the procedures developed for qualified immunity defense could help accomplish those goals. The procedural framework of the qualified immunity defense could also reduce the number of shareholder derivative lawsuits that proceed to discovery and trial, and could potentially lessen the filings of such lawsuits.

Just like the business judgment defense, the qualified immunity defense is a standard. ${ }^{260}$ In adopting the current formulation of the qualified immunity doctrine, the Supreme Court implicitly desired "to avoid federal damages liability for harms that do not clearly reach constitutional dimensions" and thus "eschew[ed] liability except when an official's conduct violates well-established constitutional law."261 Although the actual standard for the business judgment defense will differ from the qualified immunity defense since constitutional law is not the basis of decision in shareholder derivative litigation, limiting the scope of director liability may reinforce the authority that directors possess by law to manage the corporation as well as avoid litigation and director liability for minor or debatable board decisions.

Similar to the qualified immunity defense, the value of the business judgment defense would be enhanced by an early decision on the applicability of the defense and by recognition of a right not to stand trial (to the benefit of directors and the corporation). Arguably, some of the business judgment defense's value is destroyed when courts permit discovery or even trial to invade the directors' authority. Defendants

259. See infra notes 262-67.

260. Compare Hassel, supra note 241, at 147 (stating that qualified immunity is a standard), with Bainbridge, supra note 12, at 128 ("[T]he business judgment rule clearly is misnamed; it is a standard, not a rule."), and Branson, supra note 101, at 631 (noting the business judgment rule "has no mandatory content," "involves no substantive 'do's' or 'don'ts' for corporate directors or officers," and "entail[s] only slight review of business decisions").

261. Armacost, supra note 250 , at $679-80$ (" $[\mathrm{L}]$ imiting rather than expanding the scope of liability for constitutional violations - by authorizing its use only against clearly and 'genuinely threatening' conduct - may be the best way to reinforce the special place of constitutional rights in our jurisprudence and maintain the special status of constitutional rights in the public consciousness.") (internal footnotes omitted). 
also may immediately appeal an order denying qualified immunity because again the benefit of such immunity is destroyed if the defendant must litigate the action. Similarly, the rationale of the business judgment defense suggests that courts should decide the applicability of the defense early in litigation.

The qualified immunity defense, however, may not be a perfect analogy. Although Harlow adopted a primarily objective test, the subjective intent of the defendant arguably continues to be relevant in those cases where the defendant's mental state-intent, malice, or motive - is an element of the underlying constitutional claim. ${ }^{262}$ When the motives of the defendant must be considered in the qualified immunity analysis, presumably defendants will succeed less often on summary judgment because an analysis of the defendant's motives necessarily entails a fact-intensive review. ${ }^{263}$ For this reason, to the extent the business judgment defense and its underlying fiduciary duties are formulated as more objective standards, ${ }^{264}$ then the procedural mechanisms will more effectively preserve the defense's value and purposes. This procedural approach to the business judgment defense can accommodate proposals to broaden the fiduciary duties of directors, but subjective standards for those duties could undermine the benefits of a procedural approach.

The qualified immunity defense and the other potential analogies discussed in Part II, however, demonstrate that finding a balance between authority and accountability that satisfies everyone is impossible. For instance, the new formulation for the qualified immunity defense has been criticized for "provid[ing] several points at which the court's almost unfettered judgment determines the outcome of the application of the defense." 265 Further criticism charges:

Judges are being asked, in effect, to do what they think is right with very little clear cut guidance. While making the decision about what would be just, judges must dress up their conclusions in the complicated costume of qualified immunity. Because they appear clothed in the qualified immunity doctrine, the policy choices being made about the underlying constitutional rights are hidden. ${ }^{266}$

262. Rudovsky, supra note 256 , at $277-79$

263. Chen, supra note 241, at 262-63 (arguing that the qualified immunity defense should not be viewed as a pure question of law, and that facts play a critical role in such cases).

264. For an explanation of objective standards for the fiduciary duties, see Scarlett, supra note 3, at $632-37$.

265. Hassel, supra note 241, at 137.

266. Id. at 147. 
Others argue that the new standard results in "only plaintiffs bringing suit against the most egregious flouters of the Constitution hav[ing] any possibility of surviving a motion for summary judgment." ${ }^{267}$ Any formulation of the business judgment defense as a purely objective standard enforced through procedural mechanisms will likely generate some of the same criticisms.

\section{CONCLUSION}

As the litigation mechanism that balances directors' authority and shareholders' right to hold directors accountable, the business judgment defense serves important purposes that can benefit directors and shareholders. Indirectly, the defense helps to ensure individuals are willing to serve as directors and encourages directors to take calculated business risks. Directly, the defense protects directors from liability for honest mistakes, for unpopular business decisions, and for decisions that are seen as poor ones with the benefit of hindsight. Since there is no sign that courts or legislatures will eliminate shareholder derivative litigation or abolish the business judgment defense, the question is how to apply the business judgment defense in shareholder derivative litigation so that it promotes these important purposes and respects directors' authority, yet permits shareholders to overcome that defense in cases in which directors have abused their power.

Other areas of law must negotiate similar authority versus accountability dilemmas and may present potential analogies for resolving that dilemma in shareholder derivative litigation. For instance, the qualified immunity defense and the PLRA both utilize procedural mechanisms to ensure that the balance between authority and accountability is weighted toward authority. If a normative judgment is made that the balance in shareholder derivative litigation should continue to be weighted more toward authority as contemplated by the original rationales of the business judgment defense, then the analogy presented by the qualified immunity defense suggests procedural mechanisms that can be applied to the business judgment defense for that purpose. As the scholarship addressing the authority versus accountability dilemma in other areas of law demonstrates, however, even if such an approach

267. Freiman, supra note 254, at 68; cf. Andrew M. Siegel, The Court Against the Courts: Hostility to Litigation as an Organizing Theme in the Rehnquist Court's Jurisprudence, 84 TEX. L. REV. 1097, 1130 (2006) ("Among the significant modern doctrinal impediments to litigation, the development of 'qualified immunity' for government officials accused of violating the civil rights of private citizens almost certainly deserves pride of place.”). 
strikes a better balance between authority and accountability in the corporate context, some scholars will likely continue to call for more accountability because a perfect balance that satisfies all constituencies in all cases is impossible. 